\title{
COMPARING ABORIGINAL AND OTHER DUTIES TO CONSULT IN CANADIAN LAW
}

\author{
PETER CARVER ${ }^{*}$
}

This article compares recent Aboriginal rights and labour relations court decisions to assess the way the Canadian jurisprudence has conceptualized the duty to consult. While traditionally the duty to consult has been considered a constitutional duty, enshrined in section 35(1) of the Constitution Act, 1982 and section 2(d) of the Canadian Charter of Rights and Freedoms, the author suggests that courts have had great difficulty conceptualizing this duty as a constitutionally required process. The author's analysis reviews the sources and purposes of constitutional duties to consult and the hurdles the courts have faced in applying the duty meaningfully, and drawing on concepts from administrative law, offers a tentative solution to the problem of making consultative practices effective.
Cet article compare les récentes décisions sur les droits des Autochtones et les relations de travail dans le but d'évaluer de quelle manière la jurisprudence canadienne conceptualise l'obligation de consulter.Alors que traditionnellement l'obligation de consulter a été considérée comme une obligation constitutionnelle entérinée dans l'article 35(1) de la Loi constitutionnelle de 1982 et dans l'article 2(d) de la Charte canadienne des droits et libertés, l'auteur indique que les tribunaux ont beaucoup de mal à conceptualiser cette obligation comme étant une procédure nécessaire de par la constitution. Dans son analyse, l'auteur examine les sources et les raisons d'être de l'obligation constitutionnelle de consulter ainsi que les obstacles auxquels les tribunaux font face pour appliquer cette obligation de manière utile; l'auteur s'inspire du droit administratif pour tenter une solution au problème de rendre les pratiques consultatives efficaces.

\section{TABLE OF CONTENTS}

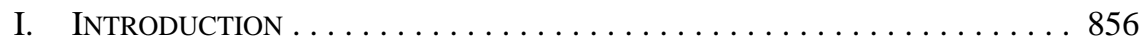

II. CONSUltATION IN THEORY AND LAW . . . . . . . . . . . . . . . . . . . . . 858

A. Procedural Fairness at Common LAW . . . . . . . . . . 859

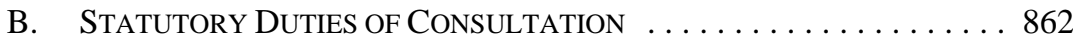

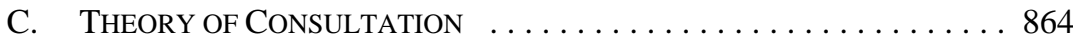

III. Constitutional Duties of Consultation . . . . . . . . . . . . . . 866

A. The Aboriginal Duty to Consult and Section 35(1) . . . . . 867

B. Collective Bargaining, Consultation, AND FREEDOM OF ASSOCIATION . . . . . . . . . . . . . . . 869

C. JUDICIAL COMPENSATION AND THE

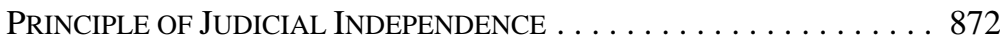

D. SOURCE AND NORMATIVE PuRPOSES OF THE

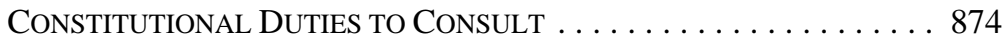

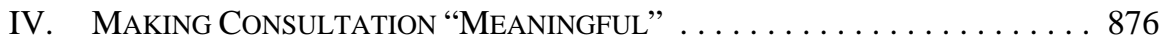

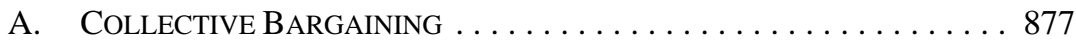

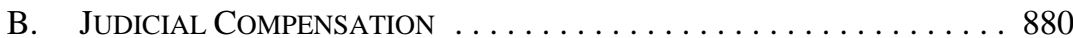

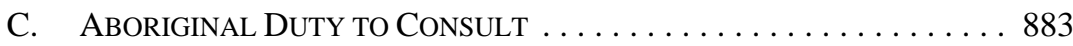

D. A TRIBUnAl MODEL FOR THE

ABORIGINAL DUTY TO CONSULT . . . . . . . . . . . . . . . . . 886

MA (Toronto), LLB (McGill), LLM (UBC), Associate Professor, Faculty of Law, and Chairperson of the Board of the Centre for Constitutional Studies, University of Alberta. The author would like to acknowledge the research assistance of Mark D Heck, LLB (Alberta). 


\section{LEGISLATIVE FUNCTIONS AND}

Constitutional Duties to Consult $\ldots \ldots \ldots \ldots \ldots \ldots \ldots . \ldots 88$

\section{INTRODUCTION}

In just a few short years, the duty to consult has emerged as a central concept in Aboriginal law in Canada. In its earliest discussions, the Supreme Court of Canada implied that this duty might on occasion amount to a substantive right to block governmental decisions over land and resources where these decisions interfered with Aboriginal title and rights. ${ }^{1}$ The Court has since made clear that the concept is largely, if not entirely, procedural in nature. The Crown owes a duty whenever it is about to take action that could infringe on proven or claimed Aboriginal rights to consult with affected Aboriginal communities, and where appropriate, to adjust its plans accordingly. The Court has made clear, however, that this right does not extend to a veto over exercises of sovereign Crown authority.

In late 2010, the Supreme Court of Canada issued decisions in two cases dealing with the relationship between administrative law principles and the constitutional duty to consult. Rio Tinto Alcan v Carrier Sekani Tribal Council ${ }^{2}$ concerned the role of a utilities regulator, the British Columbia Public Utilities Commission (PUC), in reviewing and approving an agreement for the sale of excess power by Rio Tinto Alcan to the Crown corporation British Columbia Hydro and Power Authority (BC Hydro). The power in question was produced by water flows on the Nechako River in territory subject to an unproven land title claim by the Carrier Sekani First Nation. The Tribal Council argued that the provincial Crown had breached its duty to consult with the First Nation over the purchase agreement. The case raised issues going to whether an administrative tribunal like the PUC has jurisdiction to assess an alleged breach of the Crown's duty to consult, as well as when a tribunal itself has jurisdiction to perform any required consultation. On the first issue, the Court unanimously ruled that the PUC had jurisdiction to review the consultation issue, and further, that it had made a reasonable decision in finding that no duty of consultation was owed because the purchase agreement would have no appreciable impact on claimed Aboriginal interests. On the second issue, the Court ruled that the PUC lacked the jurisdiction to conduct consultation with the Carrier Sekani had such a duty otherwise existed.

One month later the Supreme Court delivered judgment in Beckman $v$ Little Salmon/Carmacks First Nation. ${ }^{3}$ There, the issue concerned whether the government of the Yukon breached a duty to consult with the First Nation with respect to the grant to a nonAboriginal third party of land which the Crown had the right to "take up" " pursuant to the terms of a modern land claims treaty, but over which members of the First Nation had hunting and fishing rights. The Court ruled that the Crown owed a duty to consult with the First Nation on the land grant, but that the consultation required was at the low end of the spectrum for such duties. The duty had been met by the appropriate official giving notice of the pending decision, together with an opportunity for the First Nation to make submissions.

Delgamuukw v British Columbia, [1997] 3 SCR 1010 [Delgamuukw].

2010 SCC 43, [2010] 2 SCR 650 [Carrier Sekani].

2010 SCC 53, [2010] 3 SCR 103 [Carmacks].

Ibid at para 53, citing Mikisew Cree First Nation v Canada (Minister of Canadian Heritage), 2005 SCC 69, [2005] 3 SCR 388 at para 56 [Mikisew]. 
A claim by the Aboriginal claimants that the duty to consult obliged the government to accommodate their concerns and not merely consider them was rejected by the Court. In the course of its ruling the Court made several statements about what it termed the "constitutional dimension" of the duty to consult. ${ }^{5}$

The release of the Carrier Sekani and Carmacks decisions makes it timely to review the relationship between administrative law principles and the constitutional duty to consult, to identify where these two areas of law overlap and where they diverge. While the duty to consult has become the predominant constitutional means of reconciling Aboriginal and Crown interests in Canada, the idea of consultation in administrative law has generally been associated with a minimal level of procedural protection. Moreover, the Supreme Court has declined numerous opportunities to find that government actors engaged in broad policymaking activities owe a duty to consult, understood even in this minimal sense, with those affected by their decisions. The Canadian position on this question contrasts sharply with that in the United Kingdom, where common law duties of consultation have expanded over the past 20 years. The Supreme Court's disinclination to follow the British lead in this area reflects a number of concerns, including, that imposing a duty of consultation can interfere with the principle of parliamentary sovereignty, that deciding who should be involved in a consultation is more a political than a legal question, and that questions of how to enforce a duty of consultation would invite more litigation than it deserves.

Furthermore, the doctrine of procedural justice in administrative law and the Aboriginal duty to consult occupy quite different positions in contemporary Canadian legal thinking. The former is a settled and relatively well-understood body of law that is routinely employed without great difficulty in a multitude of contexts. Duty to consult cases, in contrast and as illustrated by Carrier Sekani and Carmacks, continue to wrestle with such basic questions as when the duty arises, who is obliged to perform the duty, and who should review whether the duty has been met. Were the duty to consult merely an expression of procedural justice in the field of Aboriginal rights, we might not find it so complex. The fact that courts have grappled with how to conceptualize the duty to consult would indicate that we are dealing with concepts different from each other in significant ways.

The most obvious distinction is that the duty to consult is conceived to be a constitutional obligation, with its source in section 35(1) of the Constitution Act, 1982. ${ }^{6}$ Constitutional rights and duties are more powerful than rights at common law, not least because they cannot be limited or repealed by ordinary statute. Constitutional rights also have political and symbolic importance that exceed that of the common law. For these reasons alone, we would think that the duty to consult must operate in ways unlike principles of administrative law. However, conceptualizing the duty to consult as a constitutionally required process has proven one of the greatest challenges to the jurisprudence.

In this regard, it makes sense to consider another circumstance in which the Supreme Court has recognized consultative duties in Canada's constitutional law, that of collective bargaining in the labour relations arena. Shortly after rendering judgment in Carmacks, the 
Court decided in Ontario (AG) v Fraser $^{7}$ that freedom of association in section 2(d) of the Canadian Charter of Rights and Freedoms ${ }^{8}$ incorporates a right to collective bargaining. The Fraser decision built on the Court's 2007 decision in Health Services and Support Facilities Subsector Bargaining Assn v British Columbia,${ }^{9}$ in which the Court found a duty to consult to be essential not only to collective bargaining, but also to serve as a constitutional limit on legislators' power to interfere with collective bargaining rights. Although these freedom of association cases have drawn the Court into similar debates about the scope and effectiveness of duties to consult as have characterized the Aboriginal rights cases, the areas have to date developed in isolation from each other.

This article seeks to achieve a deeper understanding of the duty to consult by comparing these recent Aboriginal rights and labour relations decisions. Part II sets the context for this discussion by exploring how the consultative relationship is understood as a theoretical construct, and in Canadian public law generally. Parts III through V of the article examine the following subjects:

- III. Sources of Constitutional Duties to Consult and Normative Purposes of Constitutional Duties to Consult

- IV. Process and Substance in Constitutional Duties to Consult

- V. Constitutional Duties to Consult and Legislative Functions

In the course of the discussion, reference will also be made to a further area of constitutionalized consultation that has not generally been discussed in those terms. Faced with a legal crisis in the mid-1990s over the issue of how Canadian governments were setting judicial compensation, the Supreme Court ruled that the governments must operate through a system of obtaining and responding to the recommendations of Judicial Compensation Commissions (JCCs). ${ }^{10}$ Subsequent decisions addressed the weight that must be given to the findings and recommendations of JCCs. ${ }^{11}$ Although the Court did not employ the phrase "duty to consult" to describe the constitutional obligation of governments in this area, it had effectively instituted a form of consultative relationship. Governments must "consult" with JCCs before exercising their lawful authority to set judicial salaries. Not surprisingly, the Court had to grapple there with similar issues of how to make consultation meaningful and effective as have arisen in the Aboriginal and labour contexts.

\section{Consultation IN THEORY AND LAW}

The Supreme Court of Canada's choice of the phrase "duty to consult" as embodying a central feature of the relationship between the Crown and Aboriginal peoples in Canada would seem at first glance unproblematic. The words themselves are familiar to everyday usage. Still, when placed in a legal context, the phrase offers something of a paradox.

2011 SCC 20, [2011] 2 SCR 3 [Fraser].

Part 1 of the Constitution Act, 1982, being Schedule B to the Canada Act 1982 (UK), 1982, c 11 [Charter].

2007 SCC 27, [2007] 2 SCR 391 [Health Services].

Reference re Remuneration of Judges of the Provincial Court of PEI, [1997] 3 SCR 3 [Provincial Court Judges Reference].

See Provincial Court Judges' Assn of New Brunswickv New Brunswick (Minister of Justice), 2005 SCC 44, [2005] 2 SCR 286 [New Brunswick Judges Reference]. 
The act of consulting carries the connotation of a voluntary activity on the part of a person who has a decision to make (the consulting party), and of the person being consulted, who may or may not be a person who anticipates being affected by the decision (the consultee or affected party). Consultation is undertaken for both parties' benefit. Put in political terms, consultation is one of the chief means by which democratic politics takes place. Decisionmakers, especially legislative decision-makers, consult with their constituents for two principal reasons. The first is to identify what their constituents want and what they are thinking about any particular matter of public policy. They need the views of their constituents as sustenance. The second reason for decision-makers to engage in consultation is to legitimize their decisions. Decisions are much more likely to be accepted by persons who feel they have participated in the decision-making process. The educative function of consultation may lead to the decision being altered in some respects and the legitimizing function of consultation will, in any event, help to reduce outright opposition. With these purposes in mind, decision-makers are likely to seek extensive opportunities for consultation, setting limits only for time and budget constraints, or at the point where they believe they have little left to learn.

A duty, on the other hand, is an obligation on a person or party; obligations, in the ordinary course of legal affairs are enforceable. How then, do we understand the idea of an enforceable obligation to undertake an act whose benefit is largely associated with it being voluntary? When we look at how the idea of a duty to consult, or its closest approximations, have been approached in "ordinary" or non-constitutional public law in Canada, we find that the judiciary has been reluctant to develop such a duty other than one which takes the form of a minimal procedural obligation.

\section{A. Procedural Fairness at COMMON LAW}

There is no specific “duty to consult” known to Canadian administrative law. That is, there is no duty on governmental actors, on whom the common law of administrative law imposes duties, to "consult with" persons affected by their decisions. Government actors owe a duty at common law to act in a procedurally fair manner, or in other words, to follow the requirements of natural justice. At a minimum, this duty means that decision-makers must give affected persons notice of the decision (or the issues to be decided) as well as an opportunity to be heard on those issues. This minimum content of the duty of fairness can look a great deal like a consultative process.

The classic formulation of the contemporary Canadian understanding of procedural fairness or natural justice remains that provided by Justice L'Heureux-Dubé for the Court in Baker v Canada (Minister of Citizenship and Immigration):

I emphasize that underlying all these factors is the notion that the purpose of the participatory rights contained within the duty of procedural fairness is to ensure that administrative decisions are made using a fair and open procedure, appropriate to the decision being made and its statutory, institutional, and social context, with an opportunity for those affected by the decision to put forward their views and evidence fully and have them considered by the decision-maker. ${ }^{12}$ 
This passage occurs in the course of the Court's explanation that the content of fairness in any particular set of circumstances falls along a spectrum of procedural protections. The similarity between a duty to consult and common law fair process is evident: both speak to the need for decision-makers to hear from and attend to the submissions of affected parties. The Supreme Court noted the similarity between consultation and procedural fairness in Haida Nation $v$ British Columbia (Minister of Forests):

While it is not useful to classify situations into watertight compartments, different situations requiring different responses can be identified. In all cases, the honour of the Crown requires that the Crown act with good faith to provide meaningful consultation appropriate to the circumstances. In discharging this duty, regard may be had to the procedural safeguards of natural justice mandated by administrative law. ${ }^{13}$

One way in which the scope of procedural fairness does not correspond to the Aboriginal duty to consult is the rule against bias. Procedural fairness includes the concept that the decision-maker must be impartial, albeit an impartiality also conditioned by context. The notion of the Crown as an unbiased decision-maker (as opposed to a decision-maker acting in good faith) is foreign to the consultative relationship. At most, the duty to consult corresponds to what Justice L’Heureux-Dubé described as the “participatory rights” within the fairness concept.

The place where the idea of consultation has received most attention in administrative law is that of legislative decision-making. This has occurred because the Supreme Court has consistently ruled that the law of procedural justice does not apply to legislative functions. The Court's firmest statement in this regard was made in Canada (AG) v Inuit Tapirisat of Canada ${ }^{14}$ a case dealing with a form of statutory appeal of a Canadian Radio-television and Telecommunications Commission telephone rate-setting decision to the federal Cabinet. Finding this decision to be legislative in nature - indeed, describing the Cabinet review power as "legislative action in its purest form"15 — the Court declined to extend to the appellants any procedural rights beyond those provided by statute. Justice Estey quoted with approval the following statement by Justice Megarry in Bates $v$ Lord Hailsham of St Marylebone: ${ }^{16}$

\footnotetext{
Let me accept that in the sphere of the so-called quasi-judicial the rules of natural justice run, and that in the administrative or executive field there is a general duty of fairness. Nevertheless, these considerations do not seem to me to affect the process of legislation, whether primary or delegated. Many of those affected by delegated legislation, and affected very substantially, are never consulted in the process of enacting that legislation; and yet they have no remedy ... I do not know of any implied right to be consulted or make objections, or any principle upon which the courts may enjoin the legislative process at the suit of those who contend that insufficient time for consultation and consideration has been given. ${ }^{17}$
}

Justice Megarry's statement of the situation in British law no longer applies. There, a robust doctrine of a duty to consult on legislative or policy-oriented decision-making based

2004 SCC 73, [2004] 3 SCR 511 at para 41 [Haida Nation]. [1980] 2 SCR 735 [Inuit Tapirisat].

Ibid at 754 .

[1972] 1 WLR 1373 at 1378 (Ch D) [Bates].

Inuit Tapirisat, supra note 14 at 757, citing Bates, ibid at 1378. 
on legitimate expectations has taken hold. ${ }^{18}$ In Canada, however, this avenue has not been followed. The doctrine of legitimate expectations giving rise to a duty to consult with respect to legislative decision-making and the kind of high-level policy decision at issue in Inuit Tapirisat has been consistently rejected. Following the Civil Service Unions case in the UK, the government of British Columbia brought forward a claim that it should have been consulted by the federal government on a change in policy affecting shared-cost programs in Reference Re Canada Assistance Plan (BC). ${ }^{19}$ The Province argued that the federal government had created by conduct and contract an enforceable expectation by the provinces that it would not reduce its contributions to the programs without first consulting them. Justice Sopinka for a unanimous Court ruled that the federal government's decision to reduce its program payments was legislative in nature. He confirmed the position taken by the Court in Inuit Tapirisat by ruling that legislative functions could not be made subject to procedural duties at common law, whether by legitimate expectation or otherwise.

The Court's ruling in CAP has been subject to criticism on the basis that a distinction can and should be drawn between law-making by Parliament and law-making by delegated bodies. In Apotex v Canada (AG) (CA), ${ }^{20}$ a pharmaceutical company sought to enforce a promise made by a Minister to engage in consultation before seeking to have Cabinet adopt a regulation affecting the company's interests. A majority of the Federal Court of Appeal declined to do so on the basis that legitimate expectations do not give rise to procedural rights with respect to decisions of a law-making nature. In dissent, Justice Evans distinguished the CAP case on the basis that it dealt with law-making by Parliament. He argued that the Cabinet, in exercising a statutory power to make regulations, should be held to a promise of consultation before making a decision, and that the duty required the granting of

a reasonable opportunity to attempt to influence its content, especially on matters of a secondary policy or technical nature. In order to honour such an undertaking the process of consultation should generally include

18 This started with a decision of the House of Lords in Council of Civil Service Unions v Minister for the Civil Service, [1984] 3 All ER 935 [Civil Service Unions], in which the Lords recognized that government's long-standing practice of consulting a union and its membership about proposed changes in contractual terms could give rise to an enforceable right to be consulted in future. This principle has given rise to a flourishing common law of duties of consultation, understood as a form of procedural entitlement that is less than natural justice, but is appropriate and applicable to policy-making decisions that would not otherwise be subject to any process requirements. A recent example is found in $R$ (on application of Greenpeace Ltd) v Secretary of State for Trade and Industry, [2007] EWHC 311 (Admin), [2007] NPC 21. There, the High Court of Justice enforced a statement made in a government white paper that the "the fullest public consultation" would be provided prior to the taking of any Cabinet level decision to reverse the government policy of not pursuing nuclear power as an option. The government had engaged in a process of issuing information and receiving responses from the public about its thinking on the issue, and had then changed the policy. Justice Sullivan ruled at para 116 that the process had gone "clearly and radically wrong" because the government failed to provide the kind of detailed information in its possession that would have permitted informed and detailed responses by groups like Greenpeace. In rendering this decision, the Court drew on extensive UK law interpreting and enforcing statutory duties to consult on government authorities. That law has described a consultative process as needing to meet the following standard: consultation must be undertaken "when proposals are still at a formative stage” (ibid at para 55), must give sufficient reasons to point the consultee to make a meaningful response, must allow adequate time for consideration and response, and the results of the consultation "must be conscientiously taken into account" (ibid) in finalizing any proposals. See also $R$ (on application of Partingdale Lane Residents Association) v Barnet London Borough Council, [2003] EWHC 947 (Admin) at para 45 (QB), citing $R v$ Brent London Borough Council, Ex parte Gunning, (1985) 84 LGR 168 at 189. 
the disclosure of the text of the proposed regulations, together with an explanatory statement, and sufficient time for this material to be studied and a response prepared. ${ }^{21}$

A key point to note from this discussion of procedural justice and law-making functions is that here consultation has been conceived as a weaker form of procedural protection than fairness, more suited to an arena of policy making where persons affected by government decisions should at least have a right to be heard, even if in an attenuated fashion.

\section{B. Statutory DUties of Consultation}

While a duty to consult as such is not recognized in Canadian common law, consultation and obligations to consult have become increasingly common in federal and provincial statutory law. A search in QuickLaw of the root term "consult" turned up 573 hits in the statutes of Alberta alone. ${ }^{22}$ In the province's Environmental Protection and Enhancement Act, ${ }^{23}$ Part I is titled "Consultation, Communication and Education," and deals with various communicative powers and duties of environmental officials and the Minister of the Environment. For example, section 14 of the Act empowers the Minister to develop environmental quality objectives "after having engaged in any public consultation that the Minister considers appropriate." ${ }^{24}$ Quebec's Regulations $A c t^{25}$ requires that every proposed regulation be gazetted before passage, and that an opportunity be given for "interested persons [to] transmit their comments to the person designated," subject to certain exceptions, including urgent situations.

Many statutory references to consultation can be described as permissive or hortatory. That is, they may authorize, even encourage, public officials to engage in consultative activities without requiring them to do so. Where statutory language creates an obligation on decision-makers to engage in consultation, however, the question of whether they have done so and what constitutes (sufficient) consultation is a justiciable issue. It falls to the judiciary to interpret and enforce the statutory language. Despite the prevalence of statutory duties to consult, Canadian courts have only infrequently been called on to engage in this interpretive exercise. Two such occasions will be described here.

In Gardner v Williams Lake (City of), ${ }^{26}$ the British Columbia Court of Appeal dealt with an argument that the municipality had failed to fulfil its statutory obligation to consult over 21 Ibid at para 136. Nevertheless, Justice Evans ruled that discussions held between the applicant and other
industry members after the regulation was enacted were sufficient, in the circumstances, to satisfy the duty to consult, even though "[i]t goes without saying that, as a general rule, consultation will generally be more effective if it occurs well before administrative action is finalized than if it occurs after the die is cast for all practical purposes, save, perhaps, for relatively minor adjustments”: ibid at para 144. In a concurring judgment in Mount Sinai Hospital Center v Quebec (Minister of Health and Social Services), 2001 SCC 41, [2001] 2 SCR 281 at para 34, Justice Binnie commented that the subject of the disagreement between the Federal Court of Appeal Justices in Apotex "remains open for another day." The Supreme Court of Canada has had no occasion since that case to consider the issue.

22 Search performed on 1 May 2012. QuickLaw, online: LexisNexis < http://www.lexisnexis.ca/en/ quicklaw $>$.

RSA 2000, c E-12.

Ibid.

RSQ, c R-18.1, s 10.

2006 BCCA 307, 228 BCAC 120. 
a proposed amendment to a community plan to allow for commercial development. ${ }^{27}$ Justice Saunders defined the content of the statutory duty in these terms:

\begin{abstract}
At a minimum, "consultation" anticipates bi-lateral communication in which the person consulted has the opportunity to question, to receive explanation and to provide comment to the local government upon the proposal. Given the requirement of a public hearing as part of the formal process of passage of an official community plan, and the express provision of s. 879 that the consultation is additional to the Public Hearing, I consider that the term "consultation" in s. 879 includes informal communications, meetings, open houses, delegations, and correspondence. The essence of the requirement is that those consulted have the opportunity to question and provide their comment, and that the local government weigh that comment, before advancing in the legislative process. ${ }^{28}$
\end{abstract}

The Court ruled that the City had met its obligation and cautioned against enforcing "form over substance" in looking too closely at the dates and details of particular meetings. ${ }^{29}$ The Court also reviewed the scope of the constitutional duty of consultation with respect to Aboriginal rights set out by the Supreme Court of Canada in Haida Nation but found it inapplicable in that the municipal case did not implicate the honour of the Crown. ${ }^{30}$

In Lakeland College Faculty Assn v Lakeland College, ${ }^{31}$ the Alberta Court of Appeal considered the meaning of a provision of the province's Colleges Act ${ }^{32}$ that required the board of a college to consult with its academic staff association before making job designations. Justice Picard discussed the statutory duty in the following terms:

Because the Colleges Act contains no definition of consultation the court must refer to dictionary definitions and judicial considerations and the purpose of the statute.... The Oxford English Dictionary, vol. 3, 2nd ed. (Oxford: Clarendon, 1989) sets out the meaning of "consult” to be "[to] confer about, deliberate upon, debate, discuss, consider (a matter)", and the meaning of "consultation” as "[a] conference in which the parties consult and deliberate; a meeting for deliberation or discussion”.... The words "consult” and "consultation" have received judicial consideration in a number of contexts, in legislation and in contracts. The following principles can be gleaned from them: consultation involves,

1. a fact-specific analysis to determine whether, under the circumstances, the measures taken do in fact constitute consultation...

The statute in question was the Local Government Act, RSBC 1996, c 323, s 879. The provision reads:

(1) During the development of an official community plan, or the repeal or amendment of an official community plan, the proposing local government must provide one or more opportunities it considers appropriate for consultation with persons, organizations and authorities it considers will be affected.

(2) For the purposes of subsection (1), the local government must

(a) consider whether the opportunities for consultation with one or more of the persons, organizations and authorities should be early and ongoing...

(3) Consultation under this section is in addition to the public hearing required under section 882(3)(d).

Supra note 26 at para 29 [emphasis added].

Ibid at para 37.

Ibid at para 24.

1998 ABCA 221, 223 AR 1.

RSA 1980, c C-18. 
2. a duty upon the decision maker to fully inform the other side of its own position, as well as to fully inform itself of the position of the other...

3. an opportunity for both sides to be heard and to state the factors they feel should guide the decision...

In summary, a consultation should involve a bilateral interaction by parties informed of each other's position where each has the opportunity to give and receive information. This definition is as much founded in common sense as in dictionaries or learned judicial writings and would seem unlikely to cause discomfort to anyone charged with consulting before making an important decision, especially those responsible for administering an educational institution. ${ }^{33}$

The Court noted that, in the post-secondary context, the redesignation of academic positions was an exceptional power for an employer not wholly consistent with other provisions of the governing collective agreement, and that academic freedom played an important underlying role in labour relations. The Court concluded that the College failed to meet its statutory obligation to consult because it did not, at any point, advise the association and the employee of the reasons why it was considering redesignating her position. ${ }^{34}$

\section{THEORY OF CONSUltation}

The question begged by the discussion so far is whether consultation represents a distinct relationship for purposes of legal analysis, or whether it is merely a subcategory of another well understood concept such as procedural justice. We have noted similarities between the duty of fairness in administrative law and a duty to consult. Both involve the making of representations in an effort to persuade or influence a decision-maker. This process is also true of negotiation. Negotiation is distinguished from procedural justice in respect of the relative position of the parties involved and the means of achieving a resolution between them. Negotiation posits a relationship of equivalence between the parties in which each holds a substantive right or rights which can be traded off for mutual benefit. A negotiated resolution is reached by the parties themselves acting voluntarily, without outside authority adjudicating the appropriate outcome. Does consultation have similarly unique features with respect to the relationship of the parties involved and the means of reaching outcomes?

Melvin Eisenberg undertook the task of identifying the features of consultation in a 1978 article in the Harvard Law Review ${ }^{35}$ in the course of examining Lon Fuller's theory of adjudicative and polycentric forms of decision-making. Fuller posited that adjudication has three component features related to the participation of affected parties in decision-making:

$33 \quad$ Supra note 31 at paras 33-38.

Ibid at para 71:

The failure of the Board to consider the collective agreement and the impact of the redesignation on Ms. Kaai’s collective bargaining rights; the failure of the Board to provide any reason for the exercise of its power under s. 10(2); the failure to provide any information for the basis for the redesignation; the narrowness of the criteria used to determine Ms. Kaai's status; and the one-sided nature of the hearing, all lead to the conclusion that the Board did not meet the standard required for a proper consultation under s. 10(2) of the Colleges Act. In the result, there was no consultation as required by the Act.

35 Melvin Aron Eisenberg, "Participation, Responsiveness, and the Consultative Process: An Essay for Lon Fuller” (1978) 92:2 Harv L Rev 410. 
"attentiveness" of the adjudicator to the submissions of the parties; "explanation” by the adjudicator of how the submissions were weighed and considered in coming to a decision; and "responsiveness" of the decision itself to the dispute as framed by the parties in their submissions. $^{36}$ In Eisenberg's view, consultative processes are distinguished from adjudicative processes largely on the third feature of responsiveness. Consultation is characterized by the absence of "strong responsiveness" between the evidence presented by the participants and the decision made:

The consultative process is distinguished from adjudication by the fact that the norm of strong responsiveness is inapplicable - that is, the decision need not proceed from or be congruent with the parties' proofs and arguments. Instead, the decisionmaker may base his decision solely on evidence he has himself collected, on his own experience, or his institutional preferences, and on rules neither adduced nor addressed by the parties. $^{37}$

Eisenberg argued that consultation is also different from polycentric decision-making decisions that turn on weighing multiple interests or variables against each other — which Fuller posited as the principal formal alternative to adjudication. Eisenberg's point is that most polycentric issues, although complex, may still be decided appropriately by the application of external substantive standards by an adjudicator. However, consultative processes are invoked where such standards are not available. Consultation combines extensive participation by affected parties together with managerial authority (or, we might say, sovereign authority) where it is desirable that decisions not be circumscribed by the submissions (and interests) of the participants. Eisenberg views consultative processes as requiring attentiveness to participants' submissions on the part of the decision-maker, enforced by judicial review directed at ensuring mere rationality by the decision-maker, not strong responsiveness.

This construct helps to clarify the distinction between procedural justice and duties to consult, including the constitutional duties in the areas of Aboriginal rights and labour relations. It draws particular attention to the mechanisms used in the jurisprudence to reinforce the attentiveness of Crown actors, and the ways in which they are called on to explain their decisions. Both are central to the issue of ensuring that consultation is meaningful, discussed in Part IV.

Eisenberg's theory points to something else. Consultation should not be viewed as "fair process lite," that is, something less than fair process. Rather, it is different than procedural justice both more and less what administrative law intends by the concept of fair process. The difference in both respects is the existence of a formal dispute, or lis, in which the decisionmaker and the affected person are participants. Consultation means something less than procedural fairness in the sense that with fairness the decision-maker is, as Eisenberg points out, bound by the evidence presented by the person affected.$^{38}$ However, consultation implies more than an opportunity to be heard when used in the sense of a shared role in decision- 
making. This distinction may assist in understanding how and why a constitutional duty to consult differs from similar duties in ordinary public law.

\section{Constitutional Duties of Consultation}

Constitutional rights and duties must find their source in the Constitution. In the usual course, this source is the text of the Constitution. However, the Supreme Court has recognized that the Constitution is not limited to the written text, but also comprises certain unwritten principles. These principles may be best understood as arising from certain structural features that require gaps to be filled in the text. Where text does not speak in a somewhat direct fashion to a procedural right or duty, the Court must locate it as some form of necessary implication or structural requirement. This exercise is highly normative. It means that the constitutional source of the purported right or duty is importantly related to its understood purpose. $^{39}$

In all three instances examined in this article in which the Supreme Court of Canada has identified forms of a duty to consult, it did not do so on the basis of express language in the text of the Constitution. This statement requires justification, because in two of the three instances the duty of consultation is traced by the Court to rights set out in constitutional text. The Court has identified the duty to consult in Aboriginal rights as arising from section 35(1) of the Constitution Act, 1982. It derived a form of duty of consultation in labour relations from freedom of association in section 2(d) of the Charter. Only in the case of the obligation on governments to consult with judicial compensation commissions did the Court identify an unwritten constitutional principle, that of judicial independence, as the source of the duty. ${ }^{40}$

In the first two instances, that of Aboriginal rights and labour relations, it might seem that the only basis for arguing that the source of obligation is extra-textual is the questionable assertion that judicial interpretation of text moves the source of rights outside the text itself. That is not, however, the meaning intended here. Rather, the claim is based on the nature of the right and duty being recognized: in each case, the constitutional duty to consult defines how substantive rights are to be exercised, but not what those substantive rights entail. In this sense, the duty to consult is secondary to, or derivative from, a primary substantive right. The Court has stated as much of the duty to consult in Aboriginal rights cases in Carmacks. ${ }^{41}$ Like unwritten principles of the Constitution, the duties to consult in Aboriginal and labour law are derived more from the structure of the Constitution and the need to "fill gaps" in its machinery

The text of the Constitution indeed refers to one duty of consultation. Section 37 of the Constitution Act, 1982, supra note 6, required the holding of a constitutional conference on the issue of Aboriginal matters immediately following the adoption of the new Constitution. This resulted in a joint conference between First Ministers and leading Aboriginal organizations in 1983, which in turn led to adoption of a new section 35.1 to replace section 37: Constitution Amendment Proclamation, 1983, SI/84-102. Section 35.1 calls for "representatives of the aboriginal peoples of Canada" to be invited to "participate in the discussions on" any proposed amendments to aspects of the Constitution dealing with Aboriginal rights. A series of three further joint conferences followed in 1984, 1985, and 1987. While some might argue that "participation" is something less than "consultation," this need not be explored here. In any event, the meaning of the words in section 35.1 and the question of its justiciability have not been addressed by a Canadian court.

$40 \quad$ Provincial Court Judges Reference, supra note 10.

41 "The concept of the duty to consult is a valuable adjunct to the honour of the Crown, but it plays a supporting role, and should not be viewed independently from its purpose": Carmacks, supra note 3 at para 44, Binnie J. Also, “[h]owever, this is not to say that every policy and procedure of the law adopted to uphold the honour of the Crown is itself to be treated as if inscribed in s. 35": ibid at para 43. 
than from the text of sections 2(d) or 35(1). They also have an instrumental character in that consultation is intended to advance or fulfil the assertion of a substantive right.

\section{A. The Aboriginal Duty to Consult And Section 35(1)}

While the Supreme Court has identified the textual source of the duty to consult in Aboriginal matters in section 35(1) of the Constitution Act, 1982, ${ }^{42}$ under the umbrella of section 35(1) the source for a duty to consult has shifted over time. The Supreme Court first located the duty in the test for justifying an infringement of an Aboriginal or treaty right. In $R v$ Sparrow, ${ }^{43}$ the Court ruled that where an Aboriginal right has been proven or a treaty right exists, the Crown nevertheless retains sovereign authority to infringe (but not to extinguish) the right. Section 35(1) requires that the Crown justify the infringement, and one aspect of justification is to demonstrate that the infringement occurred only after adequate consultation with the rights holder. This branch of the duty to consult was said to derive from the fiduciary duty between the Crown and the Aboriginal rights holders. ${ }^{44}$ In this schema, however, consultation was merely a factor in showing justification, not a requirement in all instances.

In Haida Nation, the Court located the duty to consult in the "honour of the Crown," understood as an obligation not tied to a fiduciary duty rooted in a proprietary interest. This source has assumed a much greater importance than the idea of consultation as a means of justifying the infringement of Aboriginal rights. The Court has found that the honour of the Crown in its dealings with First Nations gives rise to a duty to consult in two circumstances. In Haida Nation, a duty to consult was found to exist with respect to Crown actions that have an adverse impact on asserted Aboriginal rights, prior to proof, where the Crown is or should be aware of the impact of its action on an asserted right. In Mikisew, ${ }^{45}$ the Court extended the duty to consult to Crown action taken with respect to lands ceded to the Crown under a treaty, where the action may have an adverse impact on a First Nation's Aboriginal or treaty rights. That is, even where Crown action does not infringe treaty rights, the Crown may still have a duty to consult with respect to the adverse impact on other Aboriginal rights.

The Carrier Sekani and Carmacks cases correspond, respectively, to the two models in Haida Nation and Mikisew. The Carrier Sekani people have an unproven title claim to the land through which the Nechako River flows. They claimed that the impugned excess power purchase agreement between Rio Tinto Alcan and BC Hydro had the potential to adversely affect their title interest. The Court examined in greater detail than it has in earlier cases the factual circumstances which give rise to a duty to consult. It found there must be three factors present: (1) knowledge by the Crown, actual or constructive, of a potential Aboriginal claim

$42 \quad$ Supra note 6.

$43 \quad$ [1990] 1 SCR 1075.

44 The discussion here does not address the question of whether the provincial Crown has the same right to infringe Aboriginal and treaty rights as does the federal Crown. In Kent McNeil, "Aboriginal Rights, Resource Development, and the Source of the Provincial Duty to Consult in Haida Nation and Taku River" (2005) 29 SCLR (2d) 447, McNeil makes a cogent argument for the proposition that irrespective of satisfying any duty of consultation owed in the asserted rights stage, provinces may nevertheless incur liability in damages for infringing Aboriginal rights that are later proven. The Supreme Court recognized, as one possible example of consultation comprising part of the justification for infringement of an Aboriginal right, the discussions leading to an Aboriginal fishery at issue in $R v$ Kapp, $2008 \mathrm{SCC}$ 41, [2008] 2 SCR 483.

45 Supra note 4. See Gordon Christie, "Developing Case Law: The Future of Consultation and Accommodation” (2006) 39:1 UBC L Rev 139. 
or right; (2) contemplation by the Crown of conduct or a decision that “engages” the potential Aboriginal right; and (3) a possible and causally related adverse impact on the potential claim by the Crown conduct or decision. ${ }^{46}$ In Carrier Sekani, the Court agreed with the PUC's finding that there was insufficient evidence of any adverse impact being caused by the purchase of power agreement.

In Carrier Sekani, the Supreme Court elaborated on the purpose for recognizing a duty to consult where the Crown is contemplating action "[w]hile the treaty claims process is ongoing" ${ }^{47}$ that may adversely affect Aboriginal or treaty rights. The duty is a "corollary of the Crown's obligation to achieve the just settlement of Aboriginal claims"; ${ }^{48}$ it seeks to protect Aboriginal rights "while furthering the goals of reconciliation"; 49 it "sets the framework for dialogue prior to final resolution of claims"; 50 it is "[c]oncerned with an ethic of ongoing relationships"; 51 and the duty embodies a generative constitutional order with a “dynamic and not simply [a] static function."52 These phrases all speak to an ongoing dialogic relationship between the parties. Importantly, though, the Court emphasizes the legal context which gave rise to recognition of the duty, and in particular, the legal alternative that is presented to the courts in cases like Haida Nation and Carrier Sekani:

\footnotetext{
Absent this duty, Aboriginal groups seeking to protect their interests pending a final settlement would need to commence litigation and seek interlocutory injunctions to halt the threatening activity. These remedies have proven time-consuming, expensive, and are often ineffective. Moreover with a few exceptions, many Aboriginal groups have limited success in obtaining injunctions to halt development or activities on the land in order to protect contested Aboriginal or treaty rights.... Rather than pitting Aboriginal peoples against the Crown in the litigation process, the duty recognizes that both must work together to reconcile their interests. It also accommodates the reality that often Aboriginal peoples are involved in exploiting the resource. Shutting down development by court injunction may serve the interest of no one. The honour of the Crown is therefore best reflected by a requirement for consultation with a view to reconciliation. ${ }^{53}$
}

The Court here reminds everyone that the alternative to recognizing the duty was not the Crown's freedom to make resource development decisions unencumbered by the need to talk with Aboriginal groups with unproven claims, but rather a future of litigation and frequently checked development. The duty to consult was intended to forestall litigation and to permit resource development to continue.

This explanation of the purpose of the duty to consult does not account for the move made by the Court in Mikisew and Carmacks. Both those cases deal with land surrendered to the Crown under the terms of a treaty, and over which the Aboriginal groups in question had no residual legal interest. In both cases, the Crown's proposed action was alleged to have an adverse effect on hunting and fishing rights in the territory that were stated in the treaty to be

Carrier Sekani, supra note 2 at paras 31, 42.

Ibid at para 32.

Ibid.

Ibid at para 34 .

Ibid at para 35.

Ibid at para 38, citing Dwight G Newman, The Duty to Consult: New Relationships with Aboriginal Peoples (Saskatoon: Purich Publishing, 2009) at 21.

Carrier Sekani, ibid at para 38, citing Brian Slattery, “Aboriginal Rights and the Honour of the Crown” (2005) 29 SCLR (2d) 433 at 440.

Carrier Sekani, ibid at paras 33-34. 
subject to the Crown's right of “taking up.” In Mikisew, the honour of the Crown was said to require that a process be adopted for taking up decisions that would prevent unilateral Crown decision-making:

There is in the Minister's argument a strong advocacy of unilateral Crown action (a sort of "this is surrendered land and we can do with it what we like" approach) which not only ignores the mutual promises of the treaty, both written and oral, but also is the antithesis of reconciliation and mutual respect. It is all the more extraordinary given the Minister's acknowledgment at para. 41 of her factum that "[i]n many if not all cases the government will not be able to appreciate the effect a proposed taking up will have on the Indians' exercise of hunting, fishing and trapping rights without consultation”. 54

\section{B. Collective Bargaining, Consultation, AND FREEDOM OF ASSOCIATION}

In Health Services, the Supreme Court ruled that freedom of association in section 2(d) of the Charter includes a right to collective bargaining. ${ }^{55}$ The Court identified consultation as an essential feature of collective bargaining. However, the Court majority also ruled that the state is under a duty to consult when contemplating action, including legislative action, that would affect collective bargaining rights, particularly rights of its own employees. ${ }^{56}$

In January 2002, the government of British Columbia had enacted the Health and Social Services Delivery Improvement Act. ${ }^{57}$ The statute amended terms of existing collective agreements between public and private sector health employers and their employees, giving employers considerably greater latitude to contract out services and reorganize workplaces. The statute cancelled provisions in existing collective agreements, and barred the negotiation of the same or similar terms for a period of three years. It also contained this provision:

6(4) A provision in a collective agreement requiring an employer to consult with a trade union prior to contracting outside of the collective agreement for the provision of non-clinical services is void. ${ }^{58}$

The affected unions brought a challenge under section 2(d) of the Charter.

In the Health Services decision, the Supreme Court of Canada struck down several of the impugned provisions of the Act. ${ }^{59}$ The Court ruled that section 2(d) protects the interest

\footnotetext{
$54 \quad$ Mikisew, supra note 4 at para 49, Binnie J. See also para 53 for a discussion of the distinction between Haida Nation and Mikisew on the source and purpose of the duty to consult.

Health Services, supra note 9.

Ibid at para 88.

SBC 2002, с 2.

Ibid. This section of the Act was repealed 1 February 2004.

Supra note 9 . In so doing, the Court expressly overruled its rulings on the purpose and scope of section 2(d) of the Charter in a trilogy of labour cases decided in 1987: Reference Re Public Service Employee Relations Act (Alberta), [1987] 1 SCR 313; PSAC v Canada, [1987] 1 SCR 424; RWDSU $v$ Saskatchewan, [1987] 1 SCR 460. As affirmed in Professional Institute of the Public Service of Canada $v$ Northwest Territories (Commissioner), [1990] 2 SCR 367. Those cases stood for the proposition that freedom of association extended only to protect those activities engaged in by associations that individuals could lawfully engage in as individuals. In other words, the Court rejected a broader understanding of associations as having constitutionally protected interests in their own right. The Court first moved away from this restrictive approach to freedom of association in Dunmore v Ontario (AG), 2001 SCC 94, [2001] 3 SCR 1016 [Dunmore]. In Health Services, the Court went further by recognizing collective bargaining as an activity protected by section 2(d).
} 
workers in association have of bargaining collectively on conditions of employment. Inherent to collective bargaining is a right to engage in consultation with employers on conditions of employment. It may be more precise to say that employers have a duty to consult with associations representing their employees.

In Fraser, ${ }^{60}$ the Supreme Court of Canada dealt with the constitutionality of Ontario's Agricultural Employees Protection Act, 2002, ${ }^{61}$ which sets out a distinct labour relations regime for farm workers, who are excluded from the scheme generally applicable to employees in the province. The legislation, enacted in direct response to the earlier Supreme Court decision in Dunmore, permits farm workers to form employee associations empowered to act as bargaining agents on their behalf. ${ }^{62}$ The AEPA requires employers to consider those representations, and grants the Agriculture, Food and Rural Affairs Appeal Tribunal jurisdiction to hear and decide disputes. Unlike the provincial Labour Relations Act, ${ }^{63}$ the $A E P A$ does not require employers to bargain terms and conditions of employment with an employee association, nor does it contain mechanisms to enforce a duty on the parties to "bargain in good faith," including a mechanism that could impose terms of agreement on one or both. The United Food and Commercial Workers of Canada, acting as an employee association for farm workers in Ontario, challenged the AEPA on the basis that the omission of exclusive bargaining rights and enforcement mechanisms constituted a breach of the workers' freedom of association in section 2(d) of the Charter.

Much of the debate in Fraser between the majority judgment of Chief Justice McLachlin and Justice Lebel and the minority concurring opinions of Justices Rothstein and Abella concerned the status of the ruling in Health Sciences that freedom of association incorporated a right to collective bargaining. Justice Rothstein, writing for himself and Justice Charron, argued at length that Health Services had been wrongly decided and should be disregarded. The majority, noting among other things that it would be highly unusual for the Court to recognize error in a decision only four years old, rejected this position. This paper is more concerned, however, with what is said in both cases about duties of consultation. In this regard, the decision in Health Services is broader than that in Fraser.

There are three possible ways to understand the scope of the Charter right recognized by the Court in Health Services. The first and narrowest is that the state as executive government is obliged to consult with its own employees in the course of its labour relations activity. The Court made it clear, however, that the judgment was not restricted to this situation alone. ${ }^{64}$ The

\footnotetext{
Supra note 7.

SO 2002, с 16 [AEPA]

Dunmore, supra note 59.

SO 1995, c 1 .

Supra note 9 at para 88 :

Before going further, it may be useful to clarify who the s. 2(d) protection of collective bargaining affects, and how. The Charter applies only to state action. One form of state action is the passage of legislation. In this case, the legislature of British Columbia has passed legislation applying to relations between health care sector employers and the unions accredited to those employers. That legislation must conform to s. 2(d) of the Charter, and is void under s. 52 of the Constitution Act, 1982 if it does not (in the absence of justification under s. 1 of the Charter). A second form of state action is the situation where the government is an employer. While a private employer is not bound by s. 2(d), the government as employer must abide by the Charter, under s. 32, which provides: "This Charter applies ... (b) to the legislature and government of each province in respect of all matters within the authority of the legislature of each province." This case is concerned with an attack on government
} 
second is that the state in its legislative role is barred from enacting laws that effectively limit consultation between employees in association and their employers, whether in the private or public sector. It is this ruling that the Court found applicable in Fraser. The third possibility is that section 2(d) imposes a duty on the legislature to engage in consultation before enacting legislation that limits collective bargaining rights. Arguably, this is what the majority in Health Services intended.

The majority identified two ways in which the presence or absence of consultation in the legislative process was relevant to Charter analysis of impugned labour legislation:

(a) as going to the manner in which the alleged breach of section 2(d) has occurred;

(b) as a factor going to section 1 justification of a Charter breach.

With respect to the first of these factors, legislation must interfere with collective bargaining in a substantial way to constitute a breach of section 2(d). This is measured both by the centrality of the issue addressed by the legislation to collective bargaining, and by the manner in which it is brought about. In the case at hand, the Court found that the provisions of the impugned statute, which precluded future bargaining over contracting out, layoffs, and bumping rights, as well as seniority and job security, were issues central to collective bargaining. Even where legislation interferes with such substantial matters, however, good faith consultation over the proposed legislation might save the law from being viewed as an infringement of section 2(d): "Even where a matter is of central importance to the associational right, if the change has been made through a process of good faith consultation it is unlikely to have adversely affected the employees' right to collective bargaining. Both inquiries, as discussed earlier, are essential."65 The Court is not clear whether this "saving” effect of good faith consultation follows because it would inevitably lead to inoffensive legislation, or because it would effectively take the place of collective bargaining between employer and employee. The latter is, of course, a much more plausible idea where the employer is the government and not a private sector party.

The majority made a similar point in setting out its section 1 justification analysis in Health Services. In the proportionality stage of the Oakes ${ }^{66}$ analysis, it was found that the legislation failed the minimal impairment test. The majority expressed doubt that the statute's blanket prohibition on union-employer consultation over contracting out provisions could be viewed as minimally intrusive on the section 2(d) right. ${ }^{67}$ The Court went further to find it also

legislation; there is no allegation that the government of British Columbia, qua employer, violated s. $2(d)$ of the Charter.

$65 \quad$ Ibid at para 129.

66 $R$ v Oakes, [1986] 1 SCR 103 [Oakes]. With respect to the first two steps in the Oakes analysis, the Court in Health Services, supra note 9, accepted that controlling labour costs in the health care sector represented a pressing and substantial object, (at para 144) and that legislation giving employers greater flexibility in such matters as contracting out and reorganizing work units was rationally connected to this objective (at para 149).

Health Services, ibid at para 153:

Section 6(2) forbids any provision "that in any manner restricts, limits or regulates the right of a health sector employer to contract outside of the collective agreement”. It gives the employers absolute power to contract out of collective agreements. There is no need or incentive to consult with the union or the employees before sending the work they normally perform to an outside contractor. To forbid any contracting out clause completely and unconditionally strikes us as not minimally impairing. A more refined provision, for example, 
relevant to note that the British Columbia government had not engaged in any consultation with the union before introducing the legislation:

Legislators are not bound to consult with affected parties before passing legislation. On the other hand, it may be useful to consider, in the course of the s. 1 justification analysis, whether the government considered other options or engaged consultation with the affected parties, in choosing to adopt its preferred approach. The Court has looked at pre-legislative considerations in the past in the context of minimal impairment. This is simply evidence going to whether other options, in a range of possible options, were explored. ${ }^{68}$

The majority referred to the fact that the government gave the appellant only 20 minutes notice of its introducing the bill into the Legislative Assembly, despite having received union requests to be consulted on any proposed legislation in this area. ${ }^{69}$

Despite the majority's stating that legislators are not obliged to consult with affected parties, ${ }^{70}$ it is reasonable to ask whether a prudent legislature would now decline to engage in a consultation process. Justice Deschamps dissented on this very point, arguing that the majority was implicitly imposing a duty of consultation under section 1:

With respect to the second inquiry ("the manner in which the measure impacts on the collective right to good faith negotiation and consultation” (para. 93)), I am concerned with the way this test is restated and applied in the majority's reasons. For example, rather than focussing on the impact on the right, the majority refer to "the manner in which the government measure is accomplished" (para. 109), "the process by which the measure was implemented” (para. 112) and "the process by which the changes were made” (para. 129). With respect, these formulations imply a duty to consult that is inconsistent with the proposition that "[l]egislators are not bound to consult with affected parties before passing legislation” (para. 157), one with which I fully agree. $^{71}$

\section{Judicial Compensation AND THE PRinciple of JUDICIAL INDEPENDENCE}

In the mid-1990s, the provincial court system in Canada was in a state of crisis. Faced with large budget deficits, the governments of several provinces had frozen or rolled back public service salaries, and included in those measures compensation for provincial court judges. Judges' associations objected, arguing that unilateral reductions in judicial compensation interfered with one of the pillars of judicial independence. Some associations brought judicial

permitting contracting out after meaningful consultation with the union, might be envisaged. Ibid at para 157.

See ibid at para 7, McLachlin CJC and LeBel J:

There was no meaningful consultation with unions before it became law. The government was aware that some of the areas affected by Bill 29 were of great concern to the unions and had expressed a willingness to consult. However, in the end, consultation was minimal. A few meetings were held between representatives of the unions and the government on general issues relating to health care. These did not deal specifically with Bill 29 and the changes that it proposed. Union representatives expressed their desire to be further consulted. The Minister of Health Services telephoned a union representative 20 minutes before Bill 29 was introduced in the legislative assembly to inform the union that the government would be introducing legislation dealing with employment security and other provisions of existing collective agreements. This was the only consultation with unions before the Act was passed.

Ibid at para 157.

Ibid at para 179 . 
review to challenge the compensation measures, while a number of individual judges refused to hear cases. ${ }^{72}$ The Supreme Court of Canada heard cases from Prince Edward Island, Manitoba, and Alberta together. ${ }^{73}$ The Court's 1997 reference opinion was sweeping in theory and practice, obliging as it did Canada's provincial governments to create administrative bodies in the form of JCCs to assume a major role in setting salaries for provincial court judges.

An eight Justice majority agreed with the judges’ associations, who argued that the setting of judicial salaries raised a constitutional issue. The Court identified the source of a constitutional duty on provincial governments to adopt the JCC model in an unwritten principle of judicial independence. Specifically, the majority located a home for this principle in the reference in the Preamble to the Constitution Act, 1867 of Canada's having a "Constitution similar in principle to that of the United Kingdom."74 Chief Justice Lamer explored the history of the Act of Settlement $(1701)^{75}$ in order to find that the UK Constitution had understood judicial independence to be a constituent principle since that time. The irony of this position, as pointed out by Justice La Forest in a strongly worded dissenting opinion, was that the UK's Constitution is unwritten and rests on the foundational idea of parliamentary supremacy. ${ }^{76}$

To understand why it is appropriate to call the duty imposed on provincial governments and legislatures a "duty of consultation," it is necessary to examine the role for JCCs set out by the Court. The role is not that of an authoritative decision-maker, but rather a body with which government must consult in exercising its constitutional authority to set compensation levels. Chief Justice Lamer acknowledged that the Constitution expressly grants decision-making power over judicial compensation to what he termed the "political branches" of the state, the legislature and/or the executive. On that basis, it would be inappropriate to place authority over compensation in an administrative agency. However, the principle of judicial independence required the interposition of such an agency in the process for setting judicial compensation. Chief Justice Lamer stated:

Although provincial executives and legislatures, as the case may be, are constitutionally permitted to change or freeze judicial remuneration, those decisions have the potential to jeopardize judicial independence. The

See Provincial Court Judges Reference, supra note 10 at paras 6-7. The Supreme Court's appreciation of the seriousness of the situation is reflected in the following passage from the majority opinion of Chief Justice Lamer:

Before I begin my legal analysis, I feel compelled to comment on the unprecedented situation which these appeals represent. The independence of provincial court judges is now a live legal issue in no fewer than four of the ten provinces in the federation. These appeals have arisen from three of those provinces - Alberta, Manitoba, and Prince Edward Island ("P.E.I.") — in three different ways.... Although the cases from the different provinces are therefore varied in their origin, taken together, in my respectful view, they demonstrate that the proper constitutional relationship between the executive and the provincial court judges in those provinces has come under serious strain. Litigation, and especially litigation before this Court, is a last resort for parties who cannot agree about their legal rights and responsibilities. It is a very serious business. In these cases, it is even more serious because litigation has ensued between two primary organs of our constitutional system - the executive and the judiciary - which both serve important and interdependent roles in the Ibid. administration of justice.

(UK), 30 \& 31 Vict, c 3, reprinted in RSC 1985, App II, No 5.

Act of Settlement (1701) (UK), 12 \&13 Will 3, c 2.

Provincial Court Judges Reference, supra note 10 at paras 308-309. 
imperative of protecting the courts from political interference through economic manipulation is served by interposing an independent body - a judicial compensation commission - between the judiciary and the other branches of government. The constitutional function of this body is to depoliticize the process of determining changes or freezes to judicial remuneration. This objective would be achieved by setting that body the specific task of issuing a report on the salaries and benefits of judges to the executive and the legislature, responding to the particular proposals made by the government to increase, reduce, or freeze judges’ salaries. ${ }^{77}$

\section{SOURCE AND NoRMATIVE PuRPOSES OF THE CONSTITUTIONAL DUTIES To CONSUlT}

What normative purposes are served by the legal duties being examined — or to be more specific, why has the Supreme Court of Canada interpreted various constitutional provisions as giving rise to a duty to consult? This question is premised on the idea that the justifications normally given for the development of rules of procedural justice in administrative law are inadequate to explain a constitutional duty to consult.

The doctrine of procedural fairness serves two purposes: to encourage better decisionmaking, and to legitimize decisions in the eyes of persons affected by statutory decisions. Both purposes are referred to by Chief Justice Laskin in Nicholson $v$ Haldiman-Norfolk Regional Board of Commissioners of Police.$^{78}$ It might be suggested that the Court cited to a third and less instrumental purpose of procedural justice in Knight $v$ Indian Head School Division No $19,{ }^{79}$ where it discussed the interest of society in knowing that its delegates are acting in accordance with principles of fairness. This suggestion might be viewed as a separate point, or simply as expressing a related function of instituting fair process as a standard administrative practice across government activities. These purposes may explain why fairness principles are considered desirable; they still require being justified in terms of an overarching theory of the role of the judiciary in developing a common law of administrative practice.

Administrative law is concerned with statutorily delegated decision-making. Superior courts exercise a supervisory control over government actors who derive their authority from statutes. In this way, the supervisory jurisdiction of the courts is viewed as fulfiling a mandate implicitly granted by the legislature. With respect to procedural justice, the courts provide fair process to supplement rights extended by statute or even where a statute is silent on process, relying on an inference that legislators intend their delegates to employ fair processes in reaching their decisions. This inference is in turn supported by the principle that legislators can deny procedural rights through express statutory statement.

A basic difference between administrative law and constitutional law, then, is that while administrative law is conceived as imposing limits on the exercise of power by executive government at the instance of the sovereign legislature, constitutional law imposes limits on exercises of power by the legislature itself. One of the principal normative purposes for common law procedural justice is therefore absent when it comes to constitutional law. That

Ibid at para 166 [emphasis in original]. 
is, the courts cannot draw an inference that procedural justice is intended unless otherwise expressly denied by constitutional text. ${ }^{80}$

The Constitution concerns relationships of power expressed through legal authority and sovereignty. It is in that arena that we should search for a convincing explanation for the normative purpose of constitutional duties to consult. All three of the duties discussed here have a common etiology: they arose in circumstances of crisis, in which the legitimacy of governmental authority had been put in question. In each case, the legitimacy crisis related to a situation of conflict encountered by the Crown.

The Aboriginal duty to consult clearly relates to a widely perceived problem with the exercise of sovereignty by the Crown. The problem is historical, arising from previous unfair treatment of Aboriginals by government. This historical problem became especially acute, however, in the circumstance of ongoing resource development and land use planning in regions subject to unresolved Aboriginal title claims. In Canada, the bulk of unresolved title claims are set in British Columbia. Given the relatively recent legal recognition of the possibility of proving unextinguished title claims in British Columbia, and establishment of processes for negotiating treaties, the question of how to address exercises of Crown authority in the pre-treaty period acquired an urgency. We have noted Justice Binnie's explanation on behalf of the Supreme Court of the Hobson's Choice faced by the Canadian judiciary: countenance an indefinite period of litigation and confrontation intended to freeze development in the province pending treaty resolution, or find a way to protect Aboriginal interests within the ambit of a continued and distrusted Crown sovereignty. With the Aboriginal duty to consult, the Court chose the latter option.

To put this another way, the Crown was viewed as being in a position of conflict — caught between allocating resources for and on behalf of the community as a whole, while also being charged with respecting the constitutionally-protected rights of a minority. Where sovereign authority might be believed, even expected, to override the minority interest, an obligation to consult with the minority serves as a form of counter-balance.

Dwight Newman has written that despite the extensive Supreme Court and lower court jurisprudence on the Aboriginal duty to consult, it remains difficult to identify the single best theory to serve as justification for the duty as it has developed. He sets out four possible, overlapping justifications or purposes for the duty, which in his view explain its different emanations. ${ }^{81}$ In particular, Newman distinguishes between a results-oriented purpose of the duty that seeks to create the conditions for negotiated resolutions of resource development disputes, with purposes that focus more on the reconciliation of the rights of Aboriginal

80 See Charter, supra note 8, s 7, which guarantees “fundamental justice” might be seen as a textual source of a general presumption of fair process in government decision-making, but it is limited to interests of "life, liberty or security of person," and perhaps to other considerations going to the nature of the decision-making involved. See Bryden, on Chaoulli: Philip Bryden, "Section 7 of the Charter Outside the Criminal Context” (2005) 38:2 UBC L Rev 507.

81 Newman, supra note 51 at 15-23. Newman posits four theories as explaining aspects of the Supreme Court's duty to consult jurisprudence: (1) upholding the honour of the Crown; (2) creating an optimal context for negotiations between the Crown and Aboriginal peoples; (3) promotion of reconciliation; (4) grounding a "generative constitutional order," as Slattery suggests, supra note 52 at 434 . Newman views these more as overlapping than as mutually exclusive explanations of the duty to consult. 
peoples with Crown sovereignty on an ongoing basis, or what Brian Slattery has termed a "generative constitutional order.",

The latter terms do a better job of describing the scope and ambition of the Supreme Court's duty to consult project than does a theory going to dispute resolution. This is also a key difference between procedural fairness in administrative law and the duty to consult. Dispute resolution is not merely concerned with efficiency; how disputes are resolved says a great deal about how society as a whole works, and how democratic it is. Nevertheless, efficiency is a significant factor in measuring the success of a dispute resolution system. Without arguing the point out here, the alternatives that presented themselves to the Court in Haida Nation, the dismissal or granting of an injunction with respect to the strength of a substantive claim, seem likely to produce efficient outcomes; the same might be said of the alternative in Carmacks of finding consultation to be limited only to the terms agreed between the parties in the treaty. In both instances, however, the Court opted for a procedural solution.

This idea of a conflict of interest is also present in the contexts of public sector collective bargaining and judicial compensation. The former is the specific context in which the Health Services case arose, and it likely provides the best explanation for the surprisingly far-reaching statements the majority made about the problems a government could face should it impose legislation on its own employees without consulting them first. ${ }^{83}$

Distrust, or better, a question of legitimacy, also characterized the judicial compensation situation. There, the majority of the Court saw the problem as one of depoliticizing governmental decision-making around judicial compensation. The solution meant both removing judges from engaging directly in negotiations with government, and also ensuring that political considerations did not intrude improperly into the Crown's decision-making. ${ }^{84}$

However, the consultative solution adopted by the Court in each of these three instances is, in large part, a procedural one, not one of substantively altering the locus of sovereignty. An important question is whether and to what degree a duty to consult understood as a procedural obligation of the Crown can serve a normative purpose of restoring confidence in the constitutional distribution of sovereign power.

\section{Making Consultation "Meaningful”}

Canadian administrative law has long maintained a strict division between procedural and substantive concerns. That is, persons affected by statutorily delegated decision-making have rights to fair process irrespective of substantive right or outcome. The Supreme Court has stated on several occasions that process rights cannot be dispensed with on the basis that

82 See Slattery, ibid.

83 In this regard it is worth noting that two lower court decisions applying the Supreme Court of Canada's decision in Fraser, supra note 7 and striking down legislation for breaching the rights of employees to consultation and collective bargaining both involve statutes purporting to alter aspects of the employment relationship between governments and public employees: BC Teachers' Federation $v$ British Columbia, 2011 BCSC 469, 234 CRR (2d) 220; and Association of Justice Counsel v Canada (AG), 2011 ONSC 6435, 108 OR (3d) 516. The former case dealt with legislation enacted at the same time and as part of the same legislative program as the statute in question as Health Services, supra note 9.

84 See Provincial Court Judges Reference, supra note 10 at para 166. 
regardless of how much procedural protection an individual received, the substantive result of the dispute would have been unchanged. ${ }^{85}$

In this sense, it can be said that the effectiveness of procedural justice need not be, and is not, measured by its contribution to substantive outcomes. Fairness is assumed to be meaningful in its own right. In terms known to administrative law, it is assessed on a correctness basis - a procedure is either fair or unfair, and will be set aside if unfair. The substantive outcome of a decision-making process, on the other hand, is assessed using a standard of review analysis that may result in deference being shown to the decision-maker's judgment.

The constitutional duties to consult carry a different burden. They are intended to diminish the sovereignty of the Crown as a decision-maker, or better, to introduce a form of shared decision-making authority without altering the substantive rights or power of the parties. Precisely because the duty to consult is not intended to be instrumental to a substantive adjudication, its effectiveness falls to be measured by the degree to which it effects a change in the substantive relationship between the decision-maker and the party affected by the decision. In other words, the quality or impact of the consultation itself becomes the focus of judicial inquiry, rather than its satisfaction of relatively formal requirements, as is the case with procedural fairness. "Quality" and "impact" tend to mean the following: Has the decision-maker truly listened to, and responded to, the affected party? What evidence of response exists? And did the decision ultimately change as a result of the consultation? These are difficult questions to answer, and we see the Supreme Court struggle to find a framework for answering them in each of the three instances studied here - labour relations, judicial compensation, and Aboriginal rights litigation. The danger for the Court in each instance is to avoid the need to assess the very mental processes of Crown actors, their good faith, attentiveness, and underlying intentions.

In considering how the Court has approached this challenge, it seems helpful to start with the labour relations and judicial compensation examples. These may point to certain as yet unexplored ways forward for Aboriginal rights jurisprudence.

\section{A. Collective Bargaining}

The Supreme Court's consideration in Health Services of the nature and scope of consultation takes place with respect to its discussion of consultation as an element in the protected right of collective bargaining. The majority describes the right to collective bargaining as a procedural right (the right of workers to present, discuss, and bargain for terms of employment with the employer) and not a substantive right to any particular outcome of bargaining. To the extent freedom of association protects a right to bargain collectively, it imposes a duty on the state both as employer and as law-maker:

Section 2(d) does not guarantee the particular objectives sought through this associational activity. However, it guarantees the process through which those goals are pursued. It means that employees have the right to

85 See e.g. Kane v University of British Columbia, [1980] 1 SCR 1105; Cardinal v Director of Kent Institution, [1985] 2 SCR 643. 
unite, to present demands to health sector employers collectively and to engage in discussions in an attempt to achieve workplace-related goals. Section $2(d)$ imposes corresponding duties on government employers to agree to meet and discuss with them. It also puts constraints on the exercise of legislative powers in respect of the right to collective bargaining. ${ }^{86}$

Bargaining is more than just the right to "make representations"; it requires that there be a "meaningful process of consultation and discussion." 87 The Court described "the fundamental precept of collective bargaining" as being "the duty to consult and negotiate in good faith." 88 The Court described the goal of collective bargaining as the reconciliation and accommodation of opposed interests. "It requires both employer and employees to meet and to bargain in good faith, in the pursuit of a common goal of peaceful and productive accommodation." 89

In short, the model used by the Court for measuring whether a duty of consultation has been fulfiled is that of bargaining in good faith in the labour relations context. The Court notes that how labour boards, arbitrators, and courts have understood the concept of bargaining in good faith to include:

(i) An obligation on the parties to meet;

(ii) Dialogue and discussion of respective positions;

(iii) Genuine efforts to reach agreement. ${ }^{90}$

Bargaining in good faith does not require the parties to actually reach agreement, nor prevent one or both parties from breaking off negotiations when they believe no further progress can be made, nor does it prohibit "hard bargaining." "What is not permitted is "surface bargaining."92

$86 \quad$ Health Services, supra note 9 at para 89.

Ibid at para 114 .

Ibid at para 97.

Ibid at para 90 .

Ibid at paras 100-101.

A basic element of the duty to bargain in good faith is the obligation to actually meet and to

commit time to the process.... As explained by Adams:

The failure to meet at all is, of course, a breach of the duty. A refusal to meet unless

certain procedural preconditions are met is also a breach of the duty.

A failure to make the commitment of time and preparation required to attempt to conclude an agreement is a failure to make reasonable efforts.

Ibid at para 100, citing George W Adams, Canadian Labour Law, 2d ed (loose-leaf) (Aurora, Ont:

Canada Law Book, 1993) at 10-101, 10-106.

$91 \quad$ Health Services, ibid at para 103.

92 Ibid at para 104. For "surface bargaining", the Court quoted from its decision in Canadian Union of

Public Employees v Nova Scotia (Labour Relations Board), [1983] 2 SCR 311 at 341:

It is often difficult to determine whether a breach of the duty to bargain in good faith has

been committed. Parties to collective bargaining rarely proclaim that their aim is to avoid reaching a collective agreement. The jurisprudence recognizes a crucial distinction between "hard bargaining" and "surface bargaining"... Hard bargaining is not a violation of the duty to bargain in good faith. It is the adoption of a tough position in the hope and expectation of being able to force the other side to agree to one's terms. Hard bargaining is not a violation of the duty because there is a genuine intention to continue collective bargaining and to reach agreement. On the other hand, one is said to engage in "surface bargaining" when one pretends to want to reach agreement, but in reality has no intention of signing a collective agreement and hopes to destroy the collective bargaining relationship. It is the improper objectives which make surface bargaining a violation of the Act. The dividing line between hard bargaining and surface bargaining can be a fine one. 
The question of how to make consultation in labour relations effective or workable was a matter of debate in Fraser. The majority defined freedom of association in procedural terms as including “the right of an employees' association to make representations to the employer and have its views considered in good faith."93 The constitutional issue, then, was whether the Ontario legislation dealing with farm workers rendered a "good faith resolution of workplace issues between employees and their employer[s] effectively impossible" 94 by interfering with the consultative process. To render good faith resolution effectively impossible is a high standard to meet, and indeed the majority did not find the AEPA to cause such interference. The Court cited provisions of the statute that required employers to listen to oral representations or read written representations and give a written confirmation of having in fact read them. By implication, these obligations amount to a duty to act in good faith. The physical acts of listening and reading are tantamount to a thinking activity. Employers are being required to consider the employees' representations. ${ }^{95}$

In his critique of the majority's reasons, Justice Rothstein argued that their attempt to describe the right to collective bargaining as purely procedural is at worst disingenuous, and at best unworkable. First of all, the procedural right actually tips the balance in labour relations in a substantive way, because it contains within it a recognition by the employer that advances the employees' substantive position. ${ }^{96}$ Good faith bargaining in labour relations law, Justice Rothstein noted, incorporates a number of substantive duties, such as the duty to disclose material information in advance of negotiations and to not insist on points resulting in an impasse.

Second, the right to have representations considered in good faith is illusory if it is not made enforceable. Here, Justice Rothstein and Justice Abella were in agreement. Both argued that a right to good faith collective bargaining implies and requires a Wagner Act-like ${ }^{97}$ statutory scheme that empowers a labour tribunal to make findings of bad faith bargaining and to order such remedies as the imposing of terms of a collective agreement. ${ }^{98}$ While Justice Rothstein believed this explains why collective bargaining should not be given constitutional recognition, Justice Abella found that the lack of an enforcement mechanism of this kind renders $A E P A$ unconstitutional.

\section{$93 \quad$ Fraser, supra note 7 at para 99. \\ $94 \quad$ Ibid at para 98.}

$95 \quad$ See ibid at para 103:

The first consideration is the principle that a statute should be interpreted in a way that gives meaning and purpose to its provisions. This requires us to ask what the purpose of the requirements in ss. 5(6) and (7) is. There can only be one purpose for requiring the employer to listen to or read employee representations - to assure that the employer will in fact consider the employee representations. No labour relations purpose is served merely by pro forma listening or reading. To fulfill the purpose of reading or listening, the employer must consider the submission. Moreover, the employer must do so in good faith: consideration with a closed mind would render listening or reading the submission pointless.

Recognizing an employee association and requiring the employer to engage in collective bargaining are themselves substantive outcomes for which workers organize. In a labour context, as in other contexts, certain "procedures" are favoured because they are more likely to produce a certain outcome.

$97 \quad$ National Labor Relations Act, 29 USC § 151.

$98 \quad$ Fraser, supra note 7 at para 246, citing the Wagner model, which "refers to Canadian variants of the National Labour Relations Act, 49 Stat. 449 (1935) (the 'Wagner Act')” (Fraser, ibid at para 169). 
Chief Justice McLachlin and Justice LeBel responded in part by acknowledging that procedural rights may have substantive consequences without losing their procedural character: "However, substantive impact does not invalidate a procedural right. All procedures affect outcomes, but that does not mean that all procedural rights are unworkable. The Charter may protect collective bargaining and not the fruits of that process." 99 The majority denied that the right to collective bargaining implies any particular model of labour relations. However, when it came to assessing the constitutionality of the $A E P A$, the majority based its ruling precisely on its enforcement mechanism. While the record showed that the respondent farm workers' associations in all cases had their representations "ignored or rebuffed" by employers, the associations had not pursued enforcement before the appeal tribunal established under AEPA. ${ }^{100}$ The tribunal was authorized to cite and remedy contraventions of the statute, and could presumably develop a good faith bargaining jurisprudence: "The Tribunal may be expected to interpret its powers, in accordance with its mandate, purposively, in an effective and meaningful way. Labour tribunals enjoy substantial latitude when applying their constituent statutes to the facts of a given case."

In terms of making the duty to consult meaningful, two elements therefore emerge: first, the adoption of a model of good faith bargaining that incorporates a number of formal concepts, such as making material facts known when they become available; and second, the creation, as a matter of constitutional obligation, of a mechanism to enforce the duty to consult.

\section{B. JUDICIAL COMPENSATION}

In the Provincial Court Judges Reference, the Supreme Court set out a complete institutional framework to answer the question of how to make a consultative process effective. The framework involved the creation of a form of tribunal, the Judicial Compensation Commission. While Chief Justice Lamer stated, "I do not wish to dictate the exact shape and powers of the independent commission here,"102 he did virtually that. He called for JCCs to be comprised of persons appointed by both the judiciary and government. ${ }^{103}$ The JCCs would not have the authority to set judicial salaries, but only to make recommendations concerning salaries. Any alteration in judicial compensation being considered by government could not be put into effect prior to a JCC having first reviewed and reported on the change. JCCs must meet and report on judicial compensation at least once every three years, even in the absence of any change proposed by government. In addition, "the commission process must have a meaningful impact on the decision to set judges' salaries." 104 Chief Justice Lamer gave the following guidance in this regard:

Ibid at para 108

Ibid at para 112

102 Provincial Court Judges Reference, supra note 10 at para 167.

103 governments to determine.

What s. 11(d) requires instead is that the appointments not be entirely controlled by any one of the branches of government. The commission should have members appointed by the judiciary, on the one hand, and the legislature and the executive, on the other. The judiciary's nominees may, for example, be chosen either by the provincial judges' association, as is the case in Ontario, or by the Chief Judge of the Provincial Court in consultation with the provincial judges' association, as in British Columbia. The exact mechanism is for provincial

Ibid at para 178 . 
Furthermore, if after turning its mind to the report of the commission, the executive or the legislature, as applicable, chooses not to accept one or more of the recommendations in that report, it must be prepared to justify this decision, if necessary in a court of law. The reasons for this decision would be found either in the report of the executive responding to the contents of the commission's report, or in the recitals to the resolution of the legislature on the matter. An unjustified decision could potentially lead to a finding of unconstitutionality. The need for public justification, to my mind, emerges from one of the purposes of $\mathrm{s}$. 11(d)'s guarantee of judicial independence — to ensure public confidence in the justice system. A decision by the executive or the legislature, to change or freeze judges' salaries, and then to disagree with a recommendation not to act on that decision made by a constitutionally mandated body whose existence is premised on the need to preserve the independence of the judiciary, will only be legitimate and not be viewed as being indifferent or hostile to judicial independence, if it is supported by reasons. ${ }^{105}$

The key idea in making JCC recommendations effective, then, was the requirement that governments give reasons justifying not accepting them. The justification would be subject to judicial review on a standard of reasonableness. ${ }^{106}$

This detailed framework apparently failed to articulate a workable answer to the problem as shown by several years of further litigation between judges' associations and governments. The Supreme Court was obliged to revisit the issue in 2005 in the New Brunswick Judges Reference, dealing with disputes in Alberta, Ontario, New Brunswick, and Quebec. ${ }^{107}$

In a unanimous judgment the Court reiterated its position that JCCs must be independent, objective, and effective. It again set about the task of describing how the Commission process could be made effective without removing the government's authority to set judicial compensation. It reminded the parties that JCC recommendations had not been intended to be binding. Recommendations should have a "meaningful effect" on determining judicial salaries, but this refers to a procedural not a substantive concept:

\footnotetext{
What is a "meaningful effect"? Some of the appellants submit that "meaningful effect" means a binding effect on the government. A number of Attorneys General, by contrast, submit that "meaningful effect” requires a public and open process of recommendation and response. They urge that governments be permitted to depart from the report for a rational reason, but not to manipulate the judiciary. The essence of this appeal depends on whether "meaningful effect" means a binding effect or refers to an open process. For the reasons that follow, we conclude that it is the latter. ${ }^{108}$
}

The Court elaborated by saying a government's response to a JCC report must give "legitimate reasons” for departing from any recommendation. Among other things, this process requires that: "The commission's recommendations must be given weight. They have to be considered

Ibid at para 180 .

Ibid at para 183 .

Supra note 11 at para 12, referring to the Provincial Court Judges Reference, supra note 10: In some provinces and at the federal level, judicial commissions appear, so far, to be working satisfactorily. In other provinces, however, a pattern of routine dismissal of commission reports has resulted in litigation. Instead of diminishing friction between judges and governments, the result has been to exacerbate it. Direct negotiations no longer take place but have been replaced by litigation. These regrettable developments cast a dim light on all involved. In order to avoid future conflicts such as those at issue in the present case, the principles of the compensation commission process elaborated in the Reference must be clarified.

New Brunswick Judges Reference, ibid at para 19. 
by the judiciary and the government. The government's response must be complete, must respond to the recommendations themselves and must not simply reiterate earlier submissions that were made to and substantively addressed by the commission." 109 Having said that, the Court then set a generous standard of review for a government's response. It described the standard as that of "simple rationality," "rationality alone," and "deferential review."110 The Court set out a three-step test for determining whether a government's response meets a standard of rationality:

(1) Does the response articulate a legitimate reason for departing from the commission's recommendations?

(2) Does it rest on a reasonable factual foundation? and

(3) Viewed globally, have the purposes of the process "preserving judicial independence and depoliticizing the setting of judicial remuneration” been achieved? ${ }^{111}$

If the government's response is neither dismissive of the recommendations nor a cover for political manipulation, it will likely meet the rationality standard. ${ }^{112}$ Applying this relaxed standard, the Court ruled in favour of the governments of New Brunswick, Alberta, and Ontario. It ruled against Quebec, saying that in that case, the government's response to the JCC failed to address factors reported on at length by the Quebec JCC, and merely restated its own original position. ${ }^{113}$

The judgment in New Brunswick Judges Reference represents a retreat by the Supreme Court from the position it had taken in 1997.

In summary, we can view the judicial compensation example as an instance of consultation made meaningful or enforced through the following features: (1) creation of a tribunal with

\section{$109 \quad$ Ibid at para 23.}

$110 \quad$ Ibid at paras 29-30.

$111 \quad$ Ibid at para 31.

112 See ibid at para 39:

It is obvious that, on the basis of the test elaborated above, a bald expression of disagreement with a recommendation of the commission, or a mere assertion that judges' current salaries are "adequate", would be insufficient. It is impossible to draft a complete code for governments, and reliance has to be placed on their good faith. However, a careful application of the rationality standard dispenses with many of the rules that have dominated the discourse about the standard since the Reference. The test also dispenses with the "rules" against other methods for rejecting a commission's recommendations, such as prohibiting the reweighing of factors previously considered by the commission. The response can reweigh factors the commission has already considered as long as legitimate reasons are given for doing so. The focus is on whether the government has responded to the commission's recommendations with legitimate reasons that have a reasonable factual foundation.

$113 \quad$ See ibid at para 159:

In our comments above, we emphasized the limited nature of judicial review of the Response. Courts must stand back and refrain from intervening when they find that legitimate reasons have been given. We recognize at this stage of our inquiry that the Response does not evidence any improper political purpose or intent to manipulate or influence the judiciary. Nevertheless, on the core issue of judicial salaries, the Response does not meet the standard of rationality. In part at least, the Response fails to address the O'Donnell Committee's most important recommendations and the justifications given for them. Rather than responding, the Government appears to have been content to restate its original position without answering certain key justifications for the recommendations. 
the role of consulting with government; (2) joint appointment of tribunal members by government and the party affected; (3) a requirement of strong responsiveness through a mechanism of recommendations and reasoned response; and (4) enforcement by judicial review, albeit on a highly deferential standard of review.

\section{Aboriginal Duty to Consult}

Lorne Sossin questions whether the duty to consult is sufficient to the Supreme Court's stated purpose of reconciling Aboriginal and Crown interests. His concern is that should the duty remain a purely procedural obligation, it may actually serve as a further impediment to substantive resolutions: "More specifically, by developing a 'duty to consult and accommodate' on the part of the Crown with aboriginal communities who have asserted but not yet proven land claims, has the Court advanced the potential for reconciliation, or provided a roadmap for Government to avoid the underlying issue of the rights of aboriginal peoples?"114

Early in its discussion of a constitutional duty to consult, the Supreme Court appeared prepared to recognize substantive content to the duty to consult. In Delgamuukw, the Court stated that a duty of consultation might in some circumstances provide an Aboriginal group with the right to consent to government action, in other words, a substantive right. ${ }^{115}$ In Haida Nation, Chief Justice McLachlin largely backed away from this idea. While not denying the possibility of a right to consent, she implied that it was a remote possibility and not one that applied in the case of a mere asserted Aboriginal right: “This process [that is, consultation] does not give Aboriginal groups a veto over what can be done with land pending final proof of the claim. The Aboriginal 'consent' spoken of in Delgamuukw is appropriate only in cases of established rights, and then by no means in every case. Rather, what is required is a process of balancing interests, of give and take." ${ }^{116}$ Further, she stated the concept of natural justice gives guidance to what may be required by way of consultation: "In all cases, the honour of the Crown requires that the Crown act with good faith to provide meaningful consultation appropriate to the circumstances. In discharging this duty, regard may be had to the procedural safeguards of natural justice mandated by administrative law.”117 Chief Justice McLachlin then set out a spectrum of procedures that might be encompassed by the duty to consult. She described the low end of the spectrum as merely involving "talking together." 118 At the high end the requirements are much greater:

At the other end of the spectrum lie cases where a strong prima facie case for the claim is established, the right and potential infringement is of high significance to the Aboriginal peoples, and the risk of non-compensable damage is high. In such cases deep consultation, aimed at finding a satisfactory interim solution, may be required. While precise requirements will vary with the circumstances, the consultation required at this stage may entail the opportunity to make submissions for consideration, formal participation in the decision-making process, and provision of written reasons to show that Aboriginal concerns were considered and to reveal the

Lorne Sossin, “The Duty to Consult and Accommodate: Procedural Justice as Aboriginal Rights” (2010) 23:1 Can J Admin L \& Prac 93, abstract.

Supra note 1.

Haida Nation, supra note 13 at para 48.

Ibid at para 41.

Ibid at para 43, citing Thomas Issac \& Anthony Knox, "The Crown's Duty to Consult Aboriginal People" (2003) 41:1 Alta L Rev 49 at 61. 
impact they had on the decision. This list is neither exhaustive, nor mandatory for every case. The government may wish to adopt dispute resolution procedures like mediation or administrative regimes with impartial decision-makers in complex or difficult cases. ${ }^{119}$

In Taku River Tlingit First Nation v British Columbia (Project Assessment Director), ${ }^{120}$ released at the same time as Haida Nation, the Court placed the duty to consult owed by the government in the middle of the spectrum, and elaborated on what that could entail:

On the spectrum of consultation required by the honour of the Crown, the [Taku River Tlingit First Nation (TRTFN)] was entitled to more than the minimum receipt of notice, disclosure of information, and ensuing discussion. While it is impossible to provide a prospective checklist of the level of consultation required, it is apparent that the TRTFN was entitled to something significantly deeper than minimum consultation under the circumstances, and to a level of responsiveness to its concerns that can be characterized as accommodation. $^{121}$

At the higher end of the spectrum, then, responsiveness by the Crown is an important element of consultation. Responsiveness likely includes the giving of an explanation, or reasons, for declining to accept submissions made by the Aboriginal group in the consultation. Does accommodation take the duty to consult further? That is, does it imply a duty to make changes to a proposed action in response to submissions of the Aboriginal group? In Huu-Ay-Aht First Nation v British Columbia (Minister of Forests), Justice Dillon of the British Columbia Supreme Court stated that "[a]ccommodation begins when policy gives way to Aboriginal interests,"122 implying that the only satisfactory test for assessing whether the government has accommodated those interests is whether it has actually altered its initial plans and intentions.

In Carmacks, the Court placed the duty to consult at the lower end of the spectrum. It noted that this corresponded with the definition of consultation given in the treaty between the Yukon and the First Nations, which refers to notice, a full opportunity to make representations, and full and fair consideration by the Crown party. ${ }^{123}$ The Court held that the decision, whether to grant a 65 hectare tract of land adjoining settlement lands and over which the First Nation had recognized hunting and fishing rights, represented only a minor adverse impact. Moreover, the majority added, the decision is a yes/no matter, not one given to a wide range of possibilities. On this basis, the duty to consult did not go so far as to require accommodation by the Crown:

The First Nation goes too far, however, in seeking to impose on the territorial government not only the procedural protection of consultation but also a substantive right of accommodation. The First Nation protests that its concerns were not taken seriously — if they had been, it contends, the Paulsen application would have been denied. This overstates the scope of the duty to consult in this case. The First Nation does not have a veto over the approval process. No such substantive right is found in the treaty or in the general law, constitutional or otherwise. $^{124}$ 
However, the Court's conception of accommodation as being found at the high end of the consultation spectrum is confusing. Accommodation is a substantive outcome of a consultative process, but there is no suggestion in the case law that the Crown ever faces a duty to accommodate Aboriginal interests unless accommodation is called for by the substantive circumstances, including the seriousness of an alleged adverse impact and the relative cost and feasibility of any proposed accommodation. The determination of whether the Crown owes a duty to accommodate requires a substantive balancing of factors, achieved on the basis of what is disclosed in a consultative process, irrespective of the required degree of consultation. That is, even where circumstances dictate the most minimal duty to consult, the consultation could disclose the need to accommodate affected Aboriginal interests. Otherwise, the consultation is mere theatre, and not meaningful. On the other hand, consultation at the maximal end of the spectrum cannot require accommodative action by the Crown in the absence of substantive grounds showing it to be appropriate in the circumstances. To do otherwise is to turn the duty to consult into a veto, which falls outside the scope of the Court's interpretation of the concept.

There is one further feature of consultation discussed in Haida Nation that has a substantive aspect: the idea that "deep consultation” calls for participation in the decision-making itself. This participation should be understood as more than the right to talk or make submissions to the decision-maker, but a right to vote as a participating decision-maker. How can we understand this idea of a vote, but not a veto? The Court suggested that governments could, at least in certain circumstances, meet the obligations of a duty to consult Aboriginal groups by delegating to administrative decision-makers the task of assessing whether consultation has taken place. In so doing, Chief Justice McLachlin said the legislature would need to give guidance to the decision-maker and not merely assign it a broad discretionary function such as granting all necessary approvals.

The Court gave considerable attention to the role of regulatory tribunals with respect to the duty to consult in Carrier Sekani. It did so in the context of making its clearest statements to date about two functions bound up in the consultative relationship: (1) the performance of the Crown's duty to consult; and (2) the assessment or review of whether the performance was adequate. Confusion between these two roles has bedevilled the jurisprudence, and seems likely to continue for some time yet. In Carrier Sekani, the Aboriginal claimants variously alleged that the Public Utilities Commission (PUC) had failed both to engage in consultation on behalf of the Crown, and had wrongly concluded that consultation was not required. ${ }^{125}$

The Supreme Court ruled that whether a tribunal has jurisdiction to perform or fulfil the Crown's obligation to consult with Aboriginal groups is not settled on the basis of whether it has jurisdiction over questions of law generally, but rather on a determination of legislative intent to grant that authority. Distinguishing its decision in $R v$ Conway, ${ }^{126}$ the Court stated:

In order for a tribunal to have the power to enter into interim resource consultations with a First Nation, pending the final settlement of claims, the tribunal must be expressly or impliedly authorized to do so. The power to engage in consultation itself, as distinct from the jurisdiction to determine whether a duty to consult 
exists, cannot be inferred from the mere power to consider questions of law. Consultation itself is not a question of law; it is a distinct and often complex constitutional process and, in certain circumstances, a right involving facts, law, policy, and compromise. The tribunal seeking to engage in consultation itself must therefore possess remedial powers necessary to do what it is asked to do in connection with the consultation. The remedial powers of a tribunal will depend on that tribunal's enabling statute, and will require discerning the legislative intent. ${ }^{127}$

The PUC had jurisdiction to "consider" the duty to consult, by which the Court appears to mean the power to determine whether a duty to consult was present in the circumstances, and if so, whether the Crown had satisfied the duty.

The Court stated that the PUC's decision held that the circumstances did not give rise to a duty to consult was reviewable on a standard of reasonableness, or deference, largely because there was a significant factual component to this ruling. ${ }^{128}$ This holding is inconsistent with what the Court said in Carmacks. There, the Court concluded that the adequacy of consultation is a constitutional matter, to be assessed on a correctness standard. Where the duty has been met, the Crown's decision about what actions to take, including whether to accommodate the interests of the Aboriginal party, is reviewable on a reasonableness standard. ${ }^{129}$ This principle is closer to the administrative law model of decision-making. The performance of consultation is equivalent to the administrative decision-maker's according fair process to affected parties; the decision whether to accommodate or otherwise address the interests of the Aboriginal group is equivalent to a substantive decision subject to judicial review on an appropriate standard of review. As the Court points out in Carrier Sekani, the Crown cannot escape its constitutional duties in this scheme merely by narrowing the jurisdiction of tribunals like the PUC. Where a duty to consult exists, it must be performed by some emanation of the Crown. Further, the substantive decision made by the Crown is reviewable by the courts, either at first instance or in review of a tribunal delegated with that authority:

As the B.C. Court of Appeal rightly found, the duty to consult with Aboriginal groups, triggered when government decisions have the potential to adversely affect Aboriginal interests, is a constitutional duty invoking the honour of the Crown. It must be met. If the tribunal structure set up by the legislature is incapable of dealing with a decision's potential adverse impacts on Aboriginal interests, then the Aboriginal peoples affected must seek appropriate remedies in the courts. ${ }^{130}$

\section{A Tribunal Model for the Aboriginal Duty to Consult}

The role and status of tribunals is one of the features that stands out in considering how the Supreme Court has conceived of making consultation effective in areas of labour relations, judicial compensation, and Aboriginal rights. With Aboriginal rights issues, we see considerable ongoing confusion about the role of tribunals. In a sense, the role ascribed by the 
Court in Carrier Sekani to the PUC, while likely correct in the circumstances of the case itself, seems unhelpful, if not backward. The Court ruled that the PUC was unable to itself perform the consultation, but was empowered to assess whether a duty to consult existed and whether it had been performed. What is missing in the Aboriginal duty to consult arena is an institution (or institutions) well-suited to performing consultation; what is not missing is an institution properly placed to review the adequacy of Crown consultation. The latter role, as noted above, is and must continue to be met by Canada's superior courts acting in judicial review. Even where a Crown agency or administrative tribunal was to be fully equipped with the legislative tools and personnel resources needed to render thorough analyses of whether the Crown had met its duty to consult, a constitutional duty, a First Nation or a government unhappy with its decision on that question must surely have recourse to the judicial system to challenge its finding. Federal or provincial legislators would be no more permitted to deny access to the courts for judicial review of the adequacy of consultation than they are able to preclude review of statutorily delegated decision-making. ${ }^{131}$

However, what is missing in the Aboriginal duty to consult field is expertise in the performance of Crown consultation. It continues to be the case that consultation is the task of any and all state officials who have authority to take the action or make (and to accommodate) the planning or resource development decision that is said to adversely affect the Aboriginal interest. In Carmacks, the Court said the authority to consult rested with BC Hydro, a public utility, not a regulatory tribunal in the business of resolving disputes. This designation should strike us as odd.

In Haida Nation, the Supreme Court itself pointed to the potential value of creating a regulatory structure to guide performance of consultation on the part of the Crown:

\footnotetext{
It is open to governments to set up regulatory schemes to address the procedural requirements appropriate to different problems at different stages, thereby strengthening the reconciliation process and reducing recourse to the courts. As noted in R. v. Adams, [1996] 3 S.C.R. 101, at para. 54, the government "may not simply adopt an unstructured discretionary administrative regime which risks infringing aboriginal rights in a substantial number of applications in the absence of some explicit guidance". It should be observed that, since October 2002, British Columbia has had a Provincial Policy for Consultation with First Nations to direct the terms of provincial ministries' and agencies' operational guidelines. Such a policy, while falling short of a regulatory scheme, may guard against unstructured discretion and provide a guide for decision-makers. ${ }^{132}$
}

The kind of scheme that would be best suited to producing consistency and expertise in these functions would be a tribunal (or series of tribunals) delegated with that jurisdiction.

The Judicial Compensation Commission model operates in a different manner than the usual administrative tribunal, but may offer further guidance. First of all, the JCCs include members drawn from the affected party, the judiciary. This structure allows for a form of active participation by the affected group in a consultative process of the kind hinted at by the Court in Haida Nation, and takes the process beyond the demands of procedural justice. Second, this participatory role is linked to the fact that the JCCs do not have decision-making 
authority with respect to judicial salaries, but rather make recommendations to the government as decision-maker. The government's response to the recommendations is subject to judicial review (on a deferential standard). This "recommendation/response/review" model may be well-suited to a constitutional duty to consult. The recommendation by a well-informed and procedurally consistent body provides a substantive basis to which the Crown must respond.

Michael McClurg has pointed to a model in Canada that could operate in much this way: the resource boards established under the Nunavut Land Claims Agreement. ${ }^{133}$ The boards are comprised of persons nominated by the Nunavut government and Inuit First Nations. They make recommendations concerning development issues within their mandates (water, wildlife, etc.) to the territorial government. The latter is expected to accept and act on the recommendations unless it explains why it chooses not to do so. The government's reasons and decisions are subject to judicial review. McClurg writes that the boards are ideally positioned to carry out the Aboriginal duty to consult role, but that lower court decisions have left it unclear whether that authority will be accorded to them. Should it not, the duty would presumably continue to fall to a myriad of government officials and agencies operating at different locations in the bureaucracy. McClurg's concern seems well-placed.

\section{Legislative FunCtions AND Constitutional DUTIES To Consult}

It was noted in Part II that the Supreme Court of Canada has consistently ruled that procedural obligations at common law, including anything described as a "duty to consult," do not apply to legislative functions. ${ }^{134}$

However, constitutional rights and duties are generally understood as applying to and binding both the executive and the legislative branches of the state. Constitutional law concerns itself with limits placed on exercises of state power. On this basis, we might think that a constitutional duty of consultation, unlike procedural rights at common law, bind legislatures as well as executive government officials, that is, where such a duty exists legislators would be obliged to consult with the persons to whom the duty is owed before enacting legislation affecting the protected interests. This would represent a new obligation in the Canadian system of government. Before dismissing this possibility out of hand with respect to the Aboriginal duty to consult, it is worth stopping to recognize that something like this obligation has been acknowledged by the Supreme Court of Canada in the instances of consultation in the judicial compensation and labour relations arenas, discussed above.

Michael McClurg, “A Pragmatic Approach: The Nunavut Wildlife Management Board and the Duty to Operationalize Consultation” (2010) 9:1 Indigenous LJ 77; Canada, Department of Indian and Northern Development, Nunavut Land Claims Agreement (Ottawa: Department of Indian and Northern Development, 1993).

134 See e.g. the decision in Authorson v Canada (AG), 2003 SCC 39, [2003] 2 SCR 40 [Authorson], where the Court dealt with a challenge to a federal statute that expropriated unpaid interest on veterans' pension accounts held in trust by the government. The plaintiffs argued in part that Parliament had breached their right to "due process" under section 1(a) of the Canadian Bill of Rights, SC 1960, c 44, by not giving them notice or holding hearings on the expropriation law before enacting it. For a unanimous Court, Justice Major rejected the claim, saying:

The respondent claimed a right to notice and hearing to contest the passage of s. 5.1(4) of the

Department of Veterans Affairs Act. However, in 1960, and today, no such right exists. Long-

standing parliamentary tradition makes it clear that the only procedure due any citizen of

Canada is that proposed legislation receive three readings in the Senate and House of

Commons and that it receive Royal Assent. Once that process is completed, legislation within

Parliament's competence is unassailable (Authorson, ibid at para 37). 
With respect to the issue of judicial compensation, the unwritten principle of independence invoked by the Court in the Provincial Court Judges Reference was not limited in its binding effect only on provincial executives. Chief Justice Lamer expressly contemplated that this constitutional principle imposed similar consultative obligations on legislators in those provinces that set judicial compensation levels by statute:

\begin{abstract}
What judicial independence requires is that the executive or the legislature, whichever is vested with the authority to set judicial remuneration under provincial legislation, must formally respond to the contents of the commission's report within a specified amount of time.... If the legislature is involved in the process, the report of the commission must be laid before the legislature, when it is in session, with due diligence. If the legislature is not in session, the government may wait until a new sitting commences. The legislature should deal with the report directly, with due diligence and reasonable dispatch. ${ }^{135}$
\end{abstract}

With respect to labour relations, the majority in Health Services stated that whether a government has engaged in a consultative process with respect to proposed legislation can be a relevant factor in assessing minimal impairment under the Oakes test. This idea had been suggested by Justice L'Heureux-Dubé in her concurring opinion on behalf of four members of the Court in Corbiere $v$ Canada (Minister of Indian and Northern Affairs), ${ }^{136}$ speaking of the legal advisability of Parliament's consulting with aboriginal stakeholders when rewriting the statute struck down in that case. Richard Haigh and Michael Sobkin criticized this as an unwarranted extension of the "dialogue metaphor" from a descriptive to a prescriptive use. ${ }^{137}$

In Carrier Sekani, the Supreme Court itself declined to speculate on whether the Aboriginal duty to consult applies to law-making functions per se: "We leave for another day the question of whether government conduct includes legislative action." "138 There seems little doubt, based on the case law to date, that the duty to consult applies to most executive decision-making and activity. It appears to apply to long-range policy-making functions, what in administrative law terms might be called the "legislative end" of the spectrum of executive activity. The Court confirmed that the duty to consult is prospective in nature, and concerned only with impending adverse effect on Aboriginal interests, rather than with redressing past injuries. ${ }^{139}$ Prospectivity is, of course, a characteristic of legislative and policy-making functions. The Court then rejected two arguments made by BC Hydro and the government of British Columbia that would have narrowed the ambit of the duty to consult. First, the Court ruled that the duty's application is not limited to exercises of delegated statutory power. ${ }^{140}$ Second, the Court rejected the suggestion that the adverse effects giving rise to the duty must be material or physical effects. Both points imply that consultation must occur with longer-range planning and policy exercises, carried out at a remove from short-term decisions affecting the use of land or resources. Indeed, the Court made this clear:

Supra note 10 at para 179.

[1999] 2 SCR 203.

Richard Haigh \& Michael Sobkin, "Does the Observer Have an Effect?: An Analysis of the Use of the Dialogue Metaphor in Canada’s Courts” (2007) 45:1 Osgoode Hall LJ 67 at 77-78.

Supra note 2 at para 44.

Ibid at para 49.

"It has been held that such action is not confined to government exercise of statutory powers": ibid at para 43. See Wii'litswx v British Columbia (Minister of Forests), 2008 BCSC 1139, 4 CNLR 315 at paras 11-15. "This accords with the generous, purposive approach that must be brought to the duty to consult": Carrier Sekani, ibid. 
Further, government action [sufficient to trigger a duty to consult] is not confined to decisions or conduct which have an immediate impact on lands and resources. A potential for adverse impact suffices. Thus, the duty to consult extends to "strategic, higher level decisions" that may have an impact on Aboriginal claims and rights (Woodward, at p. 5-41 (emphasis omitted)). Examples include the transfer of tree licences which would have permitted the cutting of old-growth forest (Haida Nation); the approval of a multi-year forest management plan for a large geographic area (Klahoose First Nation v. Sunshine Coast Forest District (District Manager), 2008 BCSC 1642, [2009] 1 C.N.L.R. 110); the establishment of a review process for a major gas pipeline (Dene Tha' First Nation v. Canada (Minister of Environment), 2006 FC 1354, [2007] 1 C.N.L.R. 1, aff'd, 2008 FCA 20, 35 C.E.L.R. (3d) 1); and the conduct of a comprehensive inquiry to determine a province's infrastructure and capacity needs for electricity transmission (An Inquiry into British Columbia's Electricity Transmission Infrastructure \& Capacity Needs for the Next 30 Years, Re, 2009 CarswellBC 3637 (B.C.U.C)). ${ }^{141}$

Lower courts have shown themselves open to the idea that the Aboriginal duty to consult applies to subordinate legislation. The Federal Court of Canada decision in Dene Tha' First Nation $v$ Canada (Minister of Environment) ${ }^{142}$ dealt with a planning process intended to result in the drafting of regulations governing environmental review for the construction of a pipeline in the Mackenzie Valley. Justice Phelan did not describe the planning process and documents it produced as legislative in nature, but did view them as intending to govern the parties in the preparations for and the ultimate construction of the pipeline. The Cooperation Plan, as Justice Phelan described it, was a piece of "strategic planning." 143 It might be described as a "pre-regulatory" document.

In Adams Lake Indian Band v British Columbia (Lieutenant Governor in Council), ${ }^{144}$ the Band sought judicial review of a decision by the British Columbia provincial cabinet, effected by an Order-in-Council (OIC) enacted pursuant to the Local Government Act, ${ }^{145}$ to incorporate a township as a resort community on a popular ski area within territory subject to the Band's long-standing land claim. The respondents argued that a duty to consult could not apply to this exercise of law-making authority. Citing Supreme Court authority in an instance of municipal incorporation, Justice Bruce first indicated that the issuing of the OIC in this case appeared more a statutory decision than a legislative act: "At its core, the Lieutenant Governor in Council is exercising a statutory power of decision and that decision was imbued with the force of law by a quasi-legislative instrument." ${ }^{146}$ She continued:

The discretion exercised by the Lieutenant Governor in Council pursuant to s. 11 of the Local Government Act is a statutory power of decision reviewable pursuant to s. 5 of the Judicial Review Procedure Act and I find there is no justification for insulating Order in Council 158/2010 from the duty to consult simply because it has a legislative character. The Lieutenant Governor in Council, when exercising a statutory power of decision, must act within constitutional limits, including those imposed by s. 35 of the Constitution Act. ${ }^{147}$

\footnotetext{
$141 \quad$ Ibid at para 44.

142 2006 FC 1354, [2007] 1 CNLR 1, aff'd 2008 FCA 20, 378 NR 251.

$143 \quad$ Ibid at paras 108-109.

1442011 BCSC 266, 20 BCLR (5th) 356 [Adams Lake].

145 RSBC 1996, с 323.

146 Adams Lake, supra note 144 at para 123.

$147 \quad$ Ibid at para 128
} 
Justice Bruce declined, on a balance of convenience analysis, to quash the OIC and set aside the incorporation of the municipality, but instead issued a declaration that the Crown had breached a duty to consult the band before issuing the OIC and ordered the Crown to enter into the needed consultation. The Court retained jurisdiction over the fulfilment of its order.

Whether the duty to consult applies to legislatures, however, remains very much up in the air. This question is an important one to leave unanswered. Should the duty to consult not apply to legislatures, then presumably the right can be made subject to limitation and structuring by legislative fiat. Further, it brings into doubt the status of the duty as a “constitutional” measure.

We can in fact see in both Carrier Sekani and Carmacks a partial retrenching by the Supreme Court on the question of whether the duty to consult is a constitutional duty in the usual sense. The Court describes the Aboriginal duty to consult as "derivative” or secondary to the constitutional duty of the honour of the Crown. This characterization suggests that consultation secondary to the honour of the Crown as being a means of achieving or fulfiling the primary right. Interestingly, the same formulation of "derivative right” is applied by the Court in the Fraser case to the idea of the duty to consult and the "right to collective bargaining" with respect to freedom of association in Charter section 2(d). ${ }^{148}$ This application implies that where adequate alternatives to these derivative rights or duties are present, these need not themselves be respected by the state. It may also mean that legislatures are bound to respect the primary right, but not the derivative right. 